\title{
Dentitions of Barbclabornia (new genus, Chondrichthyes: Xenacanthiformes) from the Upper Palaeozoic of North America
}

\author{
Gary D. Johnson ${ }^{1}$
}

With 14 figures and 3 tables

\begin{abstract}
Barbclabornia luedersensis (Berman, 1970) is defined on the basis of small ( $2 \mathrm{~mm}$ high) isolated teeth that lack an intermediate cusp. It is known from the Lower Permian and possibly the Upper Pennsylvanian of North America. The two principal cusps are slightly curved orally, nearly parallel, and bear cristae mainly on their distal halves. They are cylindrical but become compressed proximally. The long axis of each cusp base is $>45^{\circ}$ to the labial margin of the tooth base. The base bears a prominent apical button in contact with the cusps; a central foramen is absent. Fewer than ten foramina occur on the aboral surface of the base, which bears a prominent concave basal tubercle. The shape of the base ranges from somewhat triangular to quadrangular. The cusps are composed of orthodentine covered by hypermineralized pallial dentine; the base is composed of orthodentine but may also contain trabecular dentine. Except for the possible occurrence of symphysial teeth, the dentition is homodont. Barbclabornia cf. B. luedersensis is stratigraphically highest in the known range of the genus and is restricted to the nearly lowermost part of the Clear Fork Group (Artinskian) of Texas. The teeth are similar to B. luedersensis, but are more robust and have a quadrangular-shaped base. Barbclabornia was large, based on an undescribed palatoquadrate some $45 \mathrm{~cm}$ long. It was probably freshwater and is most closely related to Triodus.
\end{abstract}

Key words: Chondrichthyans, Xenacanthiformes, Early Permian, North America.

\section{Zusammenfassung}

Barbclabornia luedersensis (Berman, 1970) wird anhand kleiner ( $2 \mathrm{~mm}$ Höhe), isolierter Zähne definiert, denen eine Medianspitze fehlt. Die Art ist aus dem unteren Perm und möglicherweise dem oberen Pennsylvanium von Nordamerika bekannt. Die zwei Hauptspitzen sind schwach oral geneigt, beinahe parallel und zeigen hauptsächlich auf der distalen Hälfte Cristae. Die Spitzen sind zylindrisch, erhalten allerdings proximal durch Kompression einen ovalen Umriss. Der Winkel zwischen der Längsachse jeder Spitze und dem labialen Rand der Zahnbasis beträgt mehr als $45^{\circ}$. Die Basis besitzt einen prominenten, in Kontakt mit den Spitzen stehenden Apicalhöcker, ein zentrales Foramen fehlt. Weniger als zehn Foramina sowie ein prominenter, konkav eingebuchteter Basaltuberkel befinden sich auf der aboralen Seite der Basis. Die Basis zeigt einen etwa tribis quadrangulären Umriss. Die Spitzen bestehen aus Orthodentin, ummantelt von einem hypermineralisierten Pallialdentin; die Basis besteht aus Orthodentin, kann aber auch Trabeculardentin beinhalten. Mit Ausnahme des Auftretens von Symphysenzähnen ist die Bezahnung homodent. Barbclabornia $\mathrm{cf}$. $B$. luedersensis repräsentiert den stratigraphisch jüngsten Vertreter dieser Gattung und ist etwa auf den untersten Abschnitt der Clear Fork Group (Artinskium) von Texas beschränkt. Die Zähne ähneln denen des $B$. luedersensis, sind aber robuster und besitzen eine Basis mit quadrangulärem Umriss. Ein unbeschriebenes Palatoquadratum von etwa $45 \mathrm{~cm}$ Länge weist Barbclabornia als großwüchsig aus. Es handelt sich wahrscheinlich um eine Süßwasserform. Barbclabornia besitzt enge Beziehungen zu Triodus.

Schlüsselwörter: Chondrichthyes, Xenacanthiformes, Unterperm, Nordamerika.

\section{Introduction}

This study is a continuation of a study by Johnson (1999) that reviewed the occurrences of Orthacanthus and ?Xenacanthus teeth in the Upper Palaeozoic of North America. It completes a review of known occurrences of faunas that began with Johnson (1984). The purpose of this study is to examine the taxonomy and biostratigraphy of a species of xenacanth that belongs to a new genus, but previously assigned to Xenacanthus (Berman 1970, Lund 1976).

Two additional species from North America were previously assigned to Xenacanthus.

${ }^{1}$ Department of Earth Sciences and Physics, University of South Dakota, 414 East Clark Street, Vermillion, SD $57069-$ 2390, U.S.A.

E-mail: gjohnson@usd.edu

Received September 2001, accepted December 2002 
Hampe (1989: 80) suggested that $X$. moorei (Johnson, 1980) belongs to Triodus; Schneider \& Zajíc (1994: 134) thought that species should be assigned to a new genus. I agree that it does not belong to Xenacanthus. Schneider \& Zajíc (1994: 134) correctly assigned $X$.? nebraskensis (Johnson, 1984) to Bransonella; the type species, $B$. tridentata, was also incorrectly assigned to Xenacanthus by Hansen (1996: 291).

Johnson (1999) discussed the hazards of using isolated teeth, methods of their recovery, and their fundamental characters, morphologic terminology, and the importance of the Waggoner Ranch Collection from the Lower Permian of Texas, which includes about 20,000 teeth for this study. He questioned the importance of intermediate cusp development, but in the present study, it is their absence that is a paramount character. The stratigraphic nomenclature used here (Table 1) is explained by Johnson (1996, 1999). The highly fortunate discovery of a large incomplete palatoquadrate (Oklahoma Museum of Natural History OMNH 18111; Bill May, pers. comm.), possessing teeth indistinguishable from those described here, further supports the presence of a new genus.

\section{Material and methods}

The isolated teeth used in this study are reposited in the Shuler Museum of Paleontology at Southern Methodist University, Dallas. Texas (SMU; the Waggoner Ranch Collection); the Institut für Paläontologie, Museum für Naturkunde, Humboldt-Universität zu Berlin (MB.); the Carnegie Museum of Natural History, Pittsburgh. Pennsylvania (CM); and the Texas Memorial Museum (TMM), University of Texas, Austin.

Terminology: The terms used here to describe xenacanth teeth are defined by Johnson (1999). Labiolingual and anteromedial-posterolateral are used for width and length, respectively, of the base. These terms are abbreviated $1-1$ and am-pl in the descriptions to follow. Because the anteromedial and posterolateral ends of many teeth cannot be distinguished, the abbreviation $\mathrm{am} / \mathrm{pl}$ is used in such instances. especially for the cusp margins.

The proximal portion of the principal cusps in all xenacanth teeth is compressed. The angle between the major transverse axis of this part of the cusp and a line parallel to the labial margin of the tooth base between the principal cusps is often diagnostic. The relationship is shown in Fig. 1A, D.

In Barbclabornia teeth, the only heterodonty that appears to occur is at the jaw symphysis, represented by a pair(?) of symmetrical teeth, different from adjacent teeth. The term symphysial tooth used here differs from Applegate's (1965) definition (asymmetrical teeth occurring on either side of the symphysis).

Measurements: Selected samples of teeth from the Waggoner Ranch Collection along with those from the Franklin Mall and Powhatan Point local faunas (Table 2) were measured to define the species described here and to

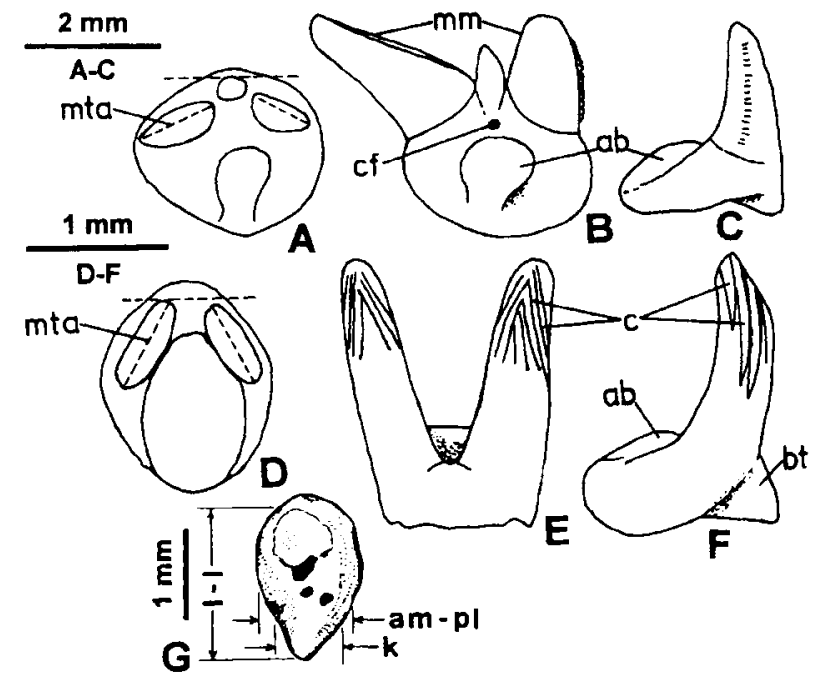

Fig. 1. Tooth morphological nomenclature and dimensions used in this paper. A, occlusal, B, lingual-occlusal, and $\mathbf{C}$, anteromedial/posterolateral views of Orthacanthus texensis (Johnson, 1999); and D, occlusal, E, labial, F, anteromedial/ posterolateral, and $\mathbf{G}$, aboral views of Barbclabornia luedersensis (Berman, 1970). The serrations on the cusp in B and cristae in $\mathrm{E}$ and $\mathrm{F}$ are slightly exaggerated. ab, apical button; am-pl, anteromedial-posterolateral dimension; bt, basal tubercle; c, cristae; cf, central foramen; $\mathbf{k}$, see text for explanation; I-I, labial-lingual dimension; mm, medial margin of cusp; mta, major transverse axis of base of cusp. Dashed lines in A and $\mathrm{D}$ demonstrate differences in the angle between the major transverse axis of the principal cusps and the labial margin of the base. A-F from Johnson 1999; fig. 1; $G$ is from the Brushy Creek I local fauna (Fig. 6).

determine if any intraspecific changes occurred stratigraphically in the sampled section represented by the Waggoner Ranch Collection. Sampling procedures, method of measurement, and the accuracy of the measurements are discussed in Johnson (1979: 90-94).

Two measurements were taken for each tooth, maximum labiolingual (1-1) width and maximum anteromedial-posterolateral (am-pl) length of the tooth base. A third measurement, designated as $\mathbf{k}$, was taken in all but the teeth from the Little Moonshine Creek local fauna. It is defined as the am-pl length of the base (parallel to the maximum am-pl measurement) measured at right angles to the $1-1$ axis of the tooth $1 / 4$ of the 1-1 width from the lingual margin (Fig. 1G). The purpose of its use is to emphasize the differences in tooth base shape between Triodus $(X$.) moorei (Johnson, 1980 ) and Barbclabornia (X.) luedersensis because they have about the same maximum dimensions. Because I have more confidence in the l-1 measurements than in the am-pl measurements of the teeth, the former are taken as the independent variable and are used as the abscissas in the linear regression plots.

\section{Systematic paleontology}

Class Chondrichthyes Huxley, 1880

Subclass Elasmobranchii Bonaparte, 1838

Order Xenacanthiformes (= Pleuracanthodii) Berg, 1940

Family Xenacanthidae Fritsch, 1889 


\section{Barbclabornia gen nov.}

Synonyms:

1970 Xenacanthus - Berman: 20-21, pl. 7, figs 8-9.

1976 Xenacanthus - Lund: 234.

1981a Xenacanthus - Johnson: fig. 3.

1987 Xenacanthus - Johnson: 22-25, figs 1, 3A-E.

1987 Xenacanthus - Murry \& Johnson: 262-263, table 1.

1992a Xenacanthus - Johnson: 41, 43-47, figs 2-4.

1996 'Xenacanthus' - Johnson: 376-379, figs 3-5.

Diagno is: Teeth small, maximum base length 0.4-5 mm. Cusps cristated, with distal portions circular in transverse section; major transverse axis of proximal end of principal cusps forms an angle of $>45^{\circ}$ with the labial margin of the base; apical button closely associated or in contact with the principal cusps; central foramen always(?) absent; intermediate cusps absent. Dentition homodont.

Type-species: Xenacanthus luedersensis (Berman, 1970) from the Lower Permian of Texas, U.S.A.

Time: Late Carboniferous (Gzhelian)?, Early Permian (Asselian-Artinskian).

Derivatio nominis: Named after Barbara and Alvie Claborn, who discovered (B. Claborn) and prepared a large tooth-bearing palatoquadrate from Oklahoma, U.S.A. All other specimens representing the genus are isolated teeth.

Remarks: Berman (1970) followed Hotton (1952) and his predecessors in using Xenacanthus because it was believed that all Upper Palaeozoic xenacanths belonged to that genus. The taxonomic nomenclature used here is discussed by Johnson (1999), as are the general characters of xenacanth teeth. The main difference is the absence of an intermediate cusp in most of the teeth described below. The angle between the transverse axes of the principal cusps and the labial margin of the base is illustrated in Fig. 1, where it is contrasted with Orthacanthus $(<45)$. This angle, $>45$ in Barbclabornia, is similar to that of Triodus (X.) moorei (Johnson, $1980)$ and Bransonella (X.?) nebraskensis (Johnson, 1984: 180). Similarly, the presence of a central foramen in Orthacanthus (Fig. 1B) and in species of ?Xenacanthus (Johnson 1999: 256, 259) contrasts with its absence in Barbclabornia. The apical button (Fig. 1) is isolated from the cusps in Orthacanthus, but its position varies in species of ?Xenacanthus (Johnson 1999: 256, 259). The surface of the base is generally smooth in Barbclabornia teeth in contrast to the rough surface in Orthacanthus (Johnson 1999: 223).

\section{Barbclabornia luedersensis (Berman, 1970)}

\section{Synonym:}

1976 Xenacanthus cf. X. leudersensis - Lund: p. 234.

Material: The teeth from 50 local faunas in the Waggoner Ranch Collection [SMU 64024-64028, 64035-64119, 64825-64826, 68807-68811, 69157-69161; and 6484464847 (Johnson 1996)] serve as the basis for this study. Included in that collection are several deformed teeth described by Johnson (1987). Also examined are 10 teeth (MB. f.7711/1-10) from the Brushy Creek I local fauna, 10 teeth (MB. f $7709 / 1-10)$ from the West Franklin Bend C local fauna, and 12 teeth (MB. f.7710/1-12) from the Mitchell Creek B/ac local fauna (Table 1). In addition, measurements of teeth from two local faunas (CM 26424, 35139-35141 and CM 26437, 26444, 35151-35153) from the Dunkard Basin are included. Except for three closely related teeth, none belonging to Barbclabornia luedersensis occurs in the Peru local fauna (Table 1; Ossian 1974, Johnson 1979: 120).

Occurrence: All occurrences documented thus far are of Asselian-Artinskian age in North America, but Barbclabornia luedersensis probably extends back to the Late Carboniferous. It may be restricted to this continent, given the apparent endemic nature of most xenacanth genera (Johnson 2000). Some would accept a Late Pennsylvanian ("Gearyan age") assignment for occurrences in the Admiral or Nocona Formation [Table 1; see Johnson \& Zidek 1981: 524-526 and Johnson 1981b; Schultze (1985: 2) considered the Gearyan as Early Permian]. Berman's (1970) main collection is from Tit Butte in the Wichita Group (Table 1). Besides the NorthCentral Texas localities, Barbclabornia is known from several localities in Oklahoma, Kansas, and the Dunkard Basin. The Oklahoma localities include the East Manitou site, the Northeast Frederick site, and the Waurika site (Olson 1967, Simpson 1979, Johnson 1979: 119). The palatoquadrate is from the Lake Frederick site in Oklahoma (Bill May, pers. comm.). Schultze (1985) reported $B .(X$.$) luedersensis from the Wreford$ Megacyclothem (Speiser Shale, Wreford Limestone and Wymore Shale Member of the Matfield Shale) in central Kansas. However, the tooth he illustrated (from the underlying Funston Limestone) is Bransonella (X.?) nebraskensis (Johnson, 1984). Both species from the Wreford Megacyclothem (Asselian-Sakmarian; Baars 1990) occur in the University of Kansas collections. The Dunkard Basin occurrences are mentioned by Lund (1976); specific localities are listed in Table 1 . In addition, two teeth from the Nineveh Limestone Member of the Green Formation at Limestone Hill, Wirt County, West Virginia, are in the University of Oklahoma (now Oklahoma Museum of Natural History) collection (OUSM 00317). Despite the earliest 
Permian occurrence of $B$. luedersensis in Kansas and the Dunkard Basin, it is absent from a highly fossiliferous locality in Texas that is probably close to the Asselian-Sakmarian boundary (Sander 1989. Johnson 1992b and study in progress).

Revised diagnosis (Berman 1970): Labiolingual dimension of tooth base nearly always greater than anteromedial-posterolateral dimension. Base composed of orthodentine and probably trabecular dentine. Apical button well developed, extending from the lingual margin to between the principal cusps, or nearly so, dominating the oral surface of the base; central foramen absent. Prominent basal tubercle with basal surface concave. sometimes flat; labial margin generally well defined. Principal cusps composed of orthodentine, variably covered by hypermineralized pallial dentine (cristae only?), compressed in proximal region, distally changing to cylindri-
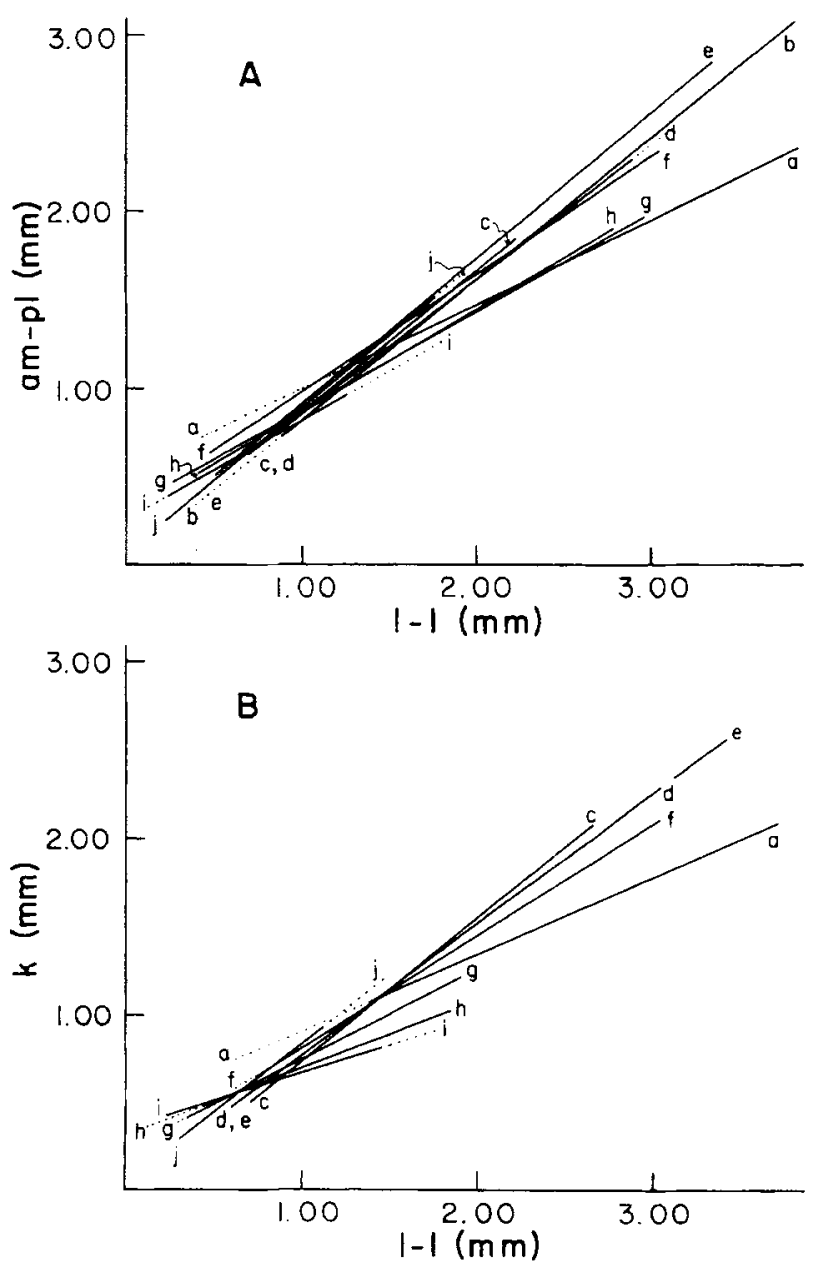

Fig. 2. A, regression of anteromedial-posterolateral (am-pl) dimension on labial-lingual (I-I) dimension for Barbclabornia teeth. B, Regression of $\mathrm{k}$ dimension on $\mathrm{k}-\mathrm{l}$ dimension for Barbclabormia teeth. Letters refer to faunas in Table 2. See text and Fig. 1 for explanation of the $\mathbf{k}$ dimension. cal, nearly parallel to each other; often slightly recurved orally, with distal tips sometimes divergent, rarely pointing in same direction; cristae well developed on labial margins, extending from distal ends proximally toward $\mathrm{am} / \mathrm{pl}$ and medial margins; cristae absent or often poorly developed on lingual margin. Intermediate cusp absent. Teeth small relative to palatoquadrate length.

Remarks: Berman (1970) based his diagnosis and description on teeth he recovered from Tit Butte (also his Site 1, the Type-locality) and Lake Kemp B and B/ac (his Site 2; see Johnson 1979 and Table 1). I have slightly modified his width-length diagnosis of the tooth base. Berman's (1970: pl. 7f, g) labial and lingual views are reversed. Availability of more teeth permits a revision of his description and discussion.

\section{Description}

Measurements: The measurements for each of the selected Wichita Group and Dunkard Group local faunas are plotted on scatter diagrams in Johnson (1979: 99-106). Measurements of teeth from the Albany and Clear Fork Groups accompany the Waggoner Ranch Collection. The statistical calculations are summarized in Table 2 and Figs 2, 3. The large sample from Mitchell Creek B/ac local fauna was split into three smaller samples to provide a check of the sampling technique. The means for these samples and also the Wolf Creek/ac sample are undoubtedly high because only about half the available small-dimension (less than $1.2 \mathrm{~mm}$ ) concentrate was utilized. The net effect is less than $-1 / 2$ standard deviation (Johnson 1979: 98 , $108,110)$, not enough to affect the trend shown in Fig. 3. A similar but negligible effect is present in the East Coffee Creek 47 data.

The trend (Fig. 3) from smaller to larger teeth occurs throughout the range of Barbclabornia luedersensis except for a leveling off in the uppermost Wichita Group (witnessed in several faunas at that horizon). The reasons for the distinctly smaller teeth in the Tit Butte fauna are unknown. Because the tendency for the increasing overlap of the standard deviations for the $1-1$, am-pl, and $\mathrm{k}$ measurements (Fig. 3) upward through the Wichita section is not disrupted, it must be independent of size. A slight reversal of this tendency occurs in the overlying Albany Group, where the largest teeth are found, but this does not appear to be significant. 


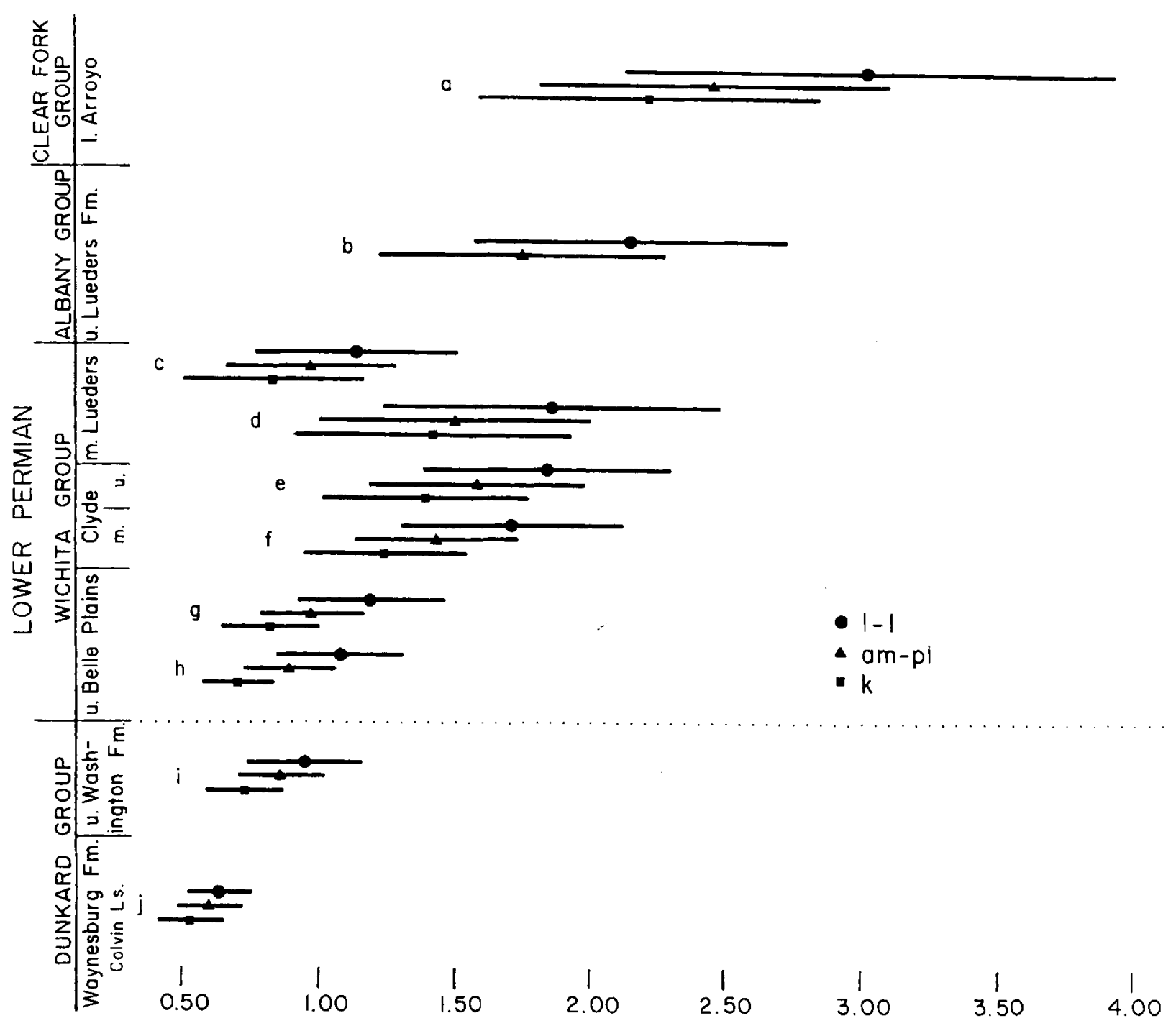

Fig. 3. Tooth dimensions (in millimeters) of Barbclabornia: Mean \pm 1 std. dev. a, B. cf. luedersensis; b-j, B. luedersensis (Berman, 1970). Letters refer to faunas in Table 2. See text and Fig. 1 for explanation of the $\mathbf{k}$ dimension; am-pl, anteromedial-posterolateral; I-I, labial-lingual.

The change in slope of the $\mathrm{k}$ on $\mathrm{l}-\mathrm{l}$ regression lines (d-i, Fig. 2B) from the upper Washington Formation to the middle Lueders demonstrates a general chronological trend from more triangular teeth (but with many exceptions in each local fauna) to teeth with a more blunt lingual margin. The validity of this trend is reduced by the older Franklin Mall teeth (regression line $\mathrm{j}$ in Fig. 2B and Fig. 4).

Tooth base: Representative samples of measured teeth from four faunas (Figs 4-7) fail to reveal any consistent pattern of foramina on the aboral surfaces. As in other species (Johnson 1999: 217), each tooth has a unique pattern. The number of foramina is fewer than ten in the examined teeth (Hampe 1993).

The apical button is accompanied by numerous foramina, which occasionally perforate the tooth base. They may perforate the lingual end of the apical button or they may be adjacent to its lingual margin. They are also adjacent to its labial margin between the principal cusps and are either single or paired, often hidden by a slight overhang of the button. A single foramen occasionally occurs along either am-pl side of the apical button near the lingual margin.

The $1-1$ width is usually greater than the am-pl length. The greatest variation in Barbclabornia luedersensis tooth bases occurs in the lingual portion (Figs 4-7). The bases of the teeth from the lower part of the Texas section (Fig. 6) tend to have triangular outlines, with the lingual tips forming an acute angle; many are rounded, however. In the upper part of the same section (Wichita Group), the lingual margins of the teeth tend to be rounded or even flat (Fig. 7). The lingual ends of the bases are rarely bifur- 


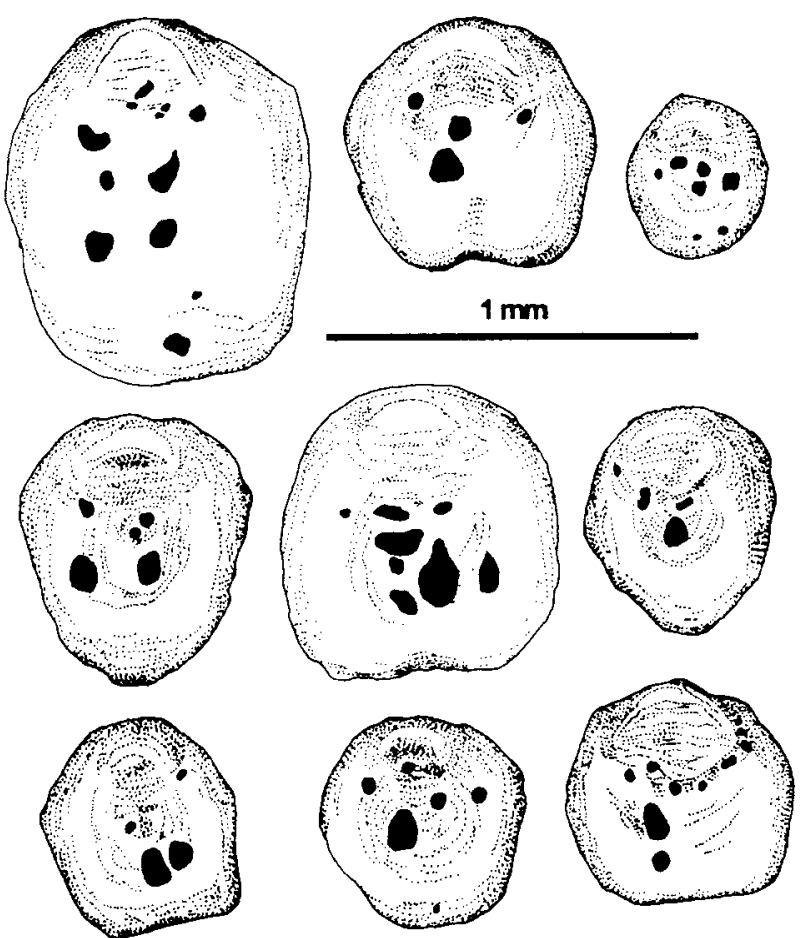

Fig. 4. Sketches (Johnson 1979: 111) of Barbclabomia luedersensis (Berman, 1970) aboral tooth surfaces from the Franklin Mall local fauna, Colvin Limestone Member. Waynesburg Formation. Labial margins face upward. cated, unlike Triodus $(X$.$) moorei teeth (Johnson$ 1980). Because bifurcated teeth occur only in the upper half of the sampled portion of the Wichita Group in Texas, this pattern may be related to tooth size (Fig. 3). A few of the larger Dunkard Basin teeth have a similar pattern (Fig. 5). About one-third of the Little Moonshine Creek teeth (Albany Group) show slight evidence of bifurcation, with only a few of the 300 teeth with an intact lignual margin having intercepted foramina. These "bifurcations," usually only slightly more than an indentation of the margin, occur throughout the size range of the Little Moonshine Creek teeth.

Principal cusps: The most striking feature of Barbclabornia luedersensis teeth is the long, slender, cristated cusps. The pattern of the cristae differs only in minor detail from one tooth to another, which might be related to position in the jaw. Generally, the cristae extend one-third to one-half the length of the cusps from the distal end, rarely as much as three-fourths on the medial margin (Figs 8C, 9D). They usually occur



Fig. 5. Sketches (Johnson 1979: 112) of Barbclabornia luedersensis (Berman. 1970) aboral tooth surfaces from the Powhatan Point local fauna, upper Washington Formation. Labial margins face upward. 


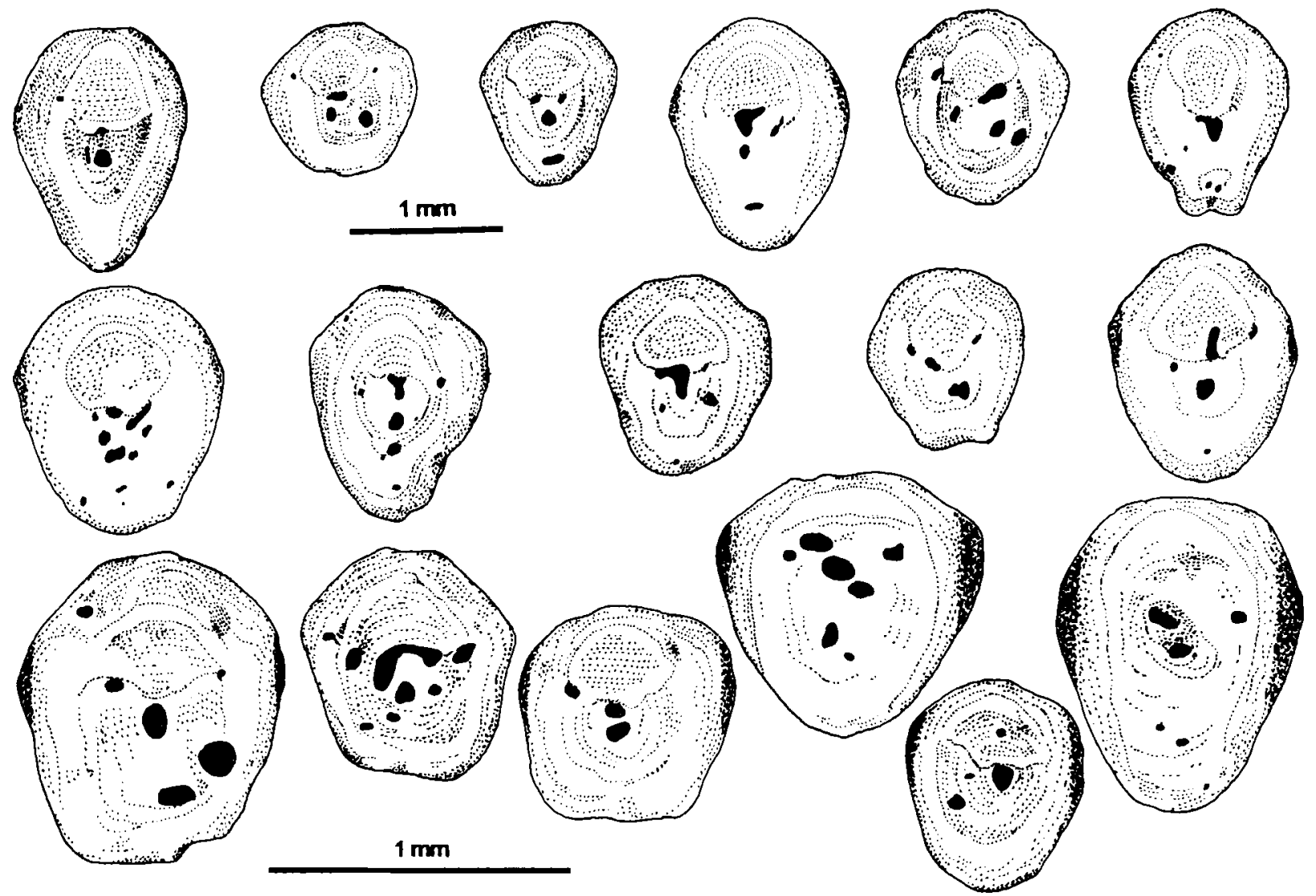

Fig. 6. Sketches (modified from Johnson 1979: 113) of Barbclabornia luedersensis (Berman, 1970) aboral tooth surfaces from the Brushy Creek I local fauna, upper Belle Plains. Upper scale bar for upper two rows; lower scale bar for remaining six sketches. Labial margins face upward

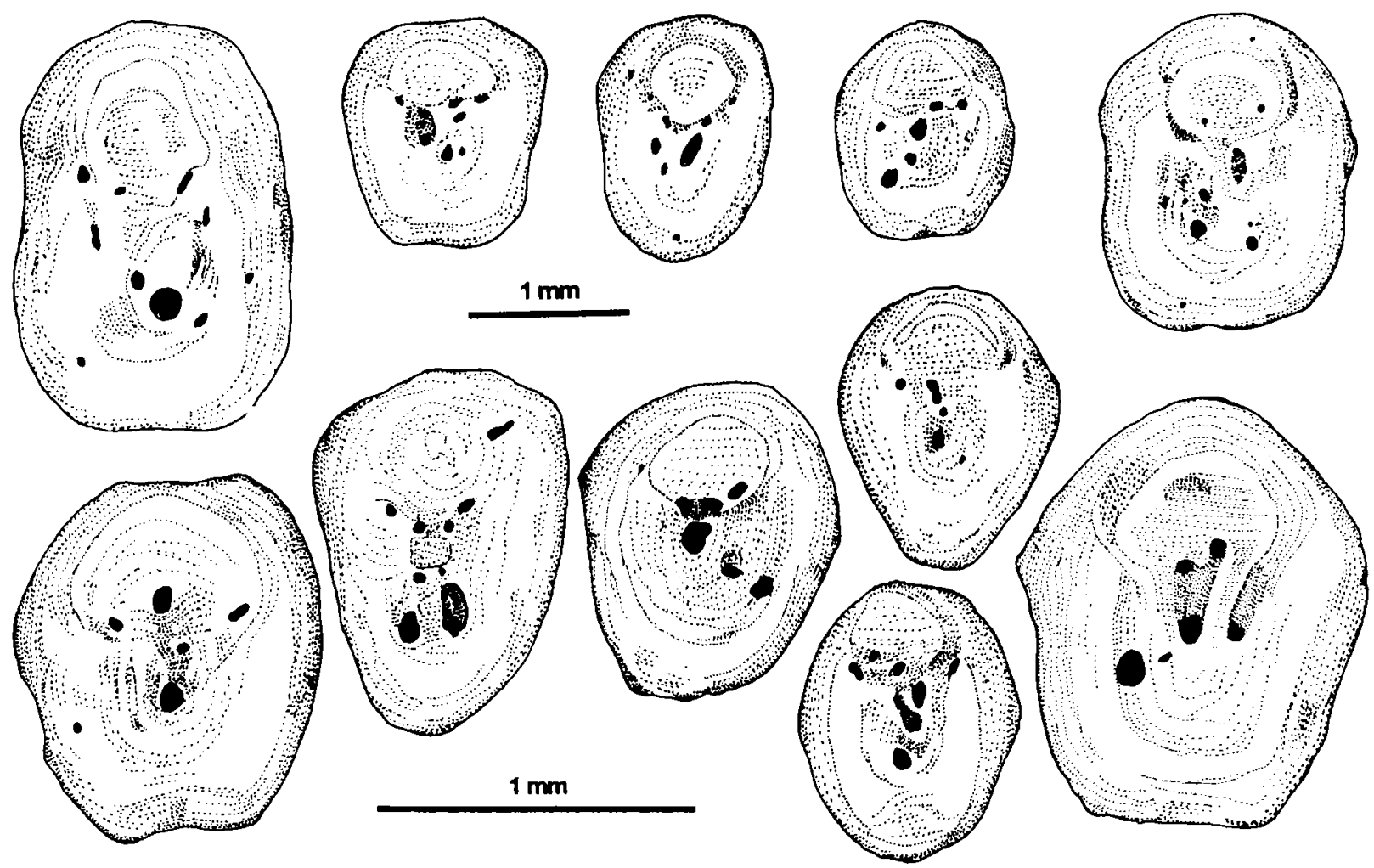

Fig. 7. Sketches (Johnson 1979: 114) of Barbclabornia luedersensis (Berman, 1970) aboral tooth surfaces from the Tit Butte/ac local fauna, middle Lueders. Upper scale bar for top row; lower scale bar for remaining six sketches. Labial margins face upward. 


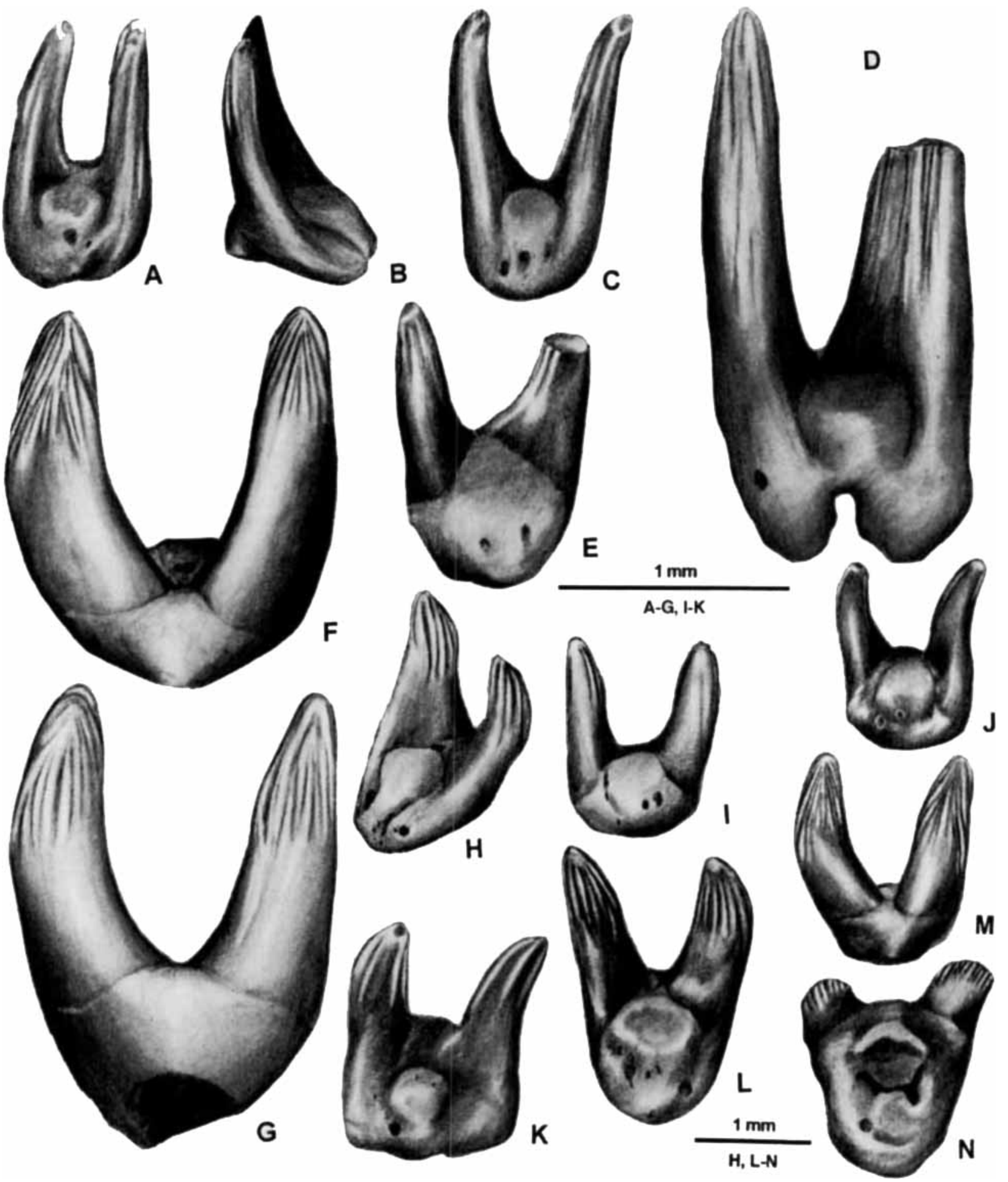

Fig. 8. Barbclabornia luedersensis (Berman. 1970). A-C, teeth from the Franklin Mall local fauna, Colvin Limestone Member, Waynesburg Formation; $\mathbf{A}$, lingual-occlusal, and $\mathbf{B}$, anteromedial/posterolateral-occlusal views of CM 35140 ; and $\mathbf{C}$, lingual-occlusal view of CM 35141. D-E. teeth from the Powhatan Point local fauna, upper Washington Formation; D, lingual view of CM 35152; and E, lingual-occlusal view of CM 35153. F-H, tooth (SMU 64026; typographical error in Johnson 1979: pl. 17) from the Brushy Creek I local fauna, upper Belle Plains; F, labial, $\mathbf{G}$, aboral-labial, and $\mathbf{H}$, oblique lingual-occlusal views; note the change in appearance of the cristae caused by minimal rotation of the tooth. I-J, teeth from the Wolf Creek/ ac local fauna, upper Belle Plains; I, lingual-occlusal view of SMU 64113; and J, lingual-occlusal view of SMU 64114. K-N, teeth from the Wolf Creek B local fauna, upper Belle Plains; $\mathbf{K}$, lingual-occlusal view of SMU 64110; and $\mathbf{L}$, lingual-occlusal, $\mathbf{M}$. labial, and $\mathbf{N}$, aboral views of SMU 64105. From Johnson (1979; 455-456). 
on all margins of the cusp at the distal end, but are often absent from the lingual margin. On the labial margin of the cusps, the cristae produce a spiral effect by curving away from the distal end toward the am-pl and medial margins (Figs 9J; $10 \mathrm{G}, \mathrm{Q} ; 11 \mathrm{C}$ ). Those originating on the medial margin of each cusp tend to curve toward the lingual margin (Figs 9I, 10J), and those originating on the $\mathrm{am} / \mathrm{pl}$ margin tend to run parallel to the axis of the cusp or curve lingually (Figs 9C, $\mathrm{G} ; 10 \mathrm{~B}, \mathrm{M} ; 11 \mathrm{~B}, \mathrm{D})$. The extent of the spiraling is seldom more than one-eighth turn. Cristae that originate on the lingual margin of the cusps extend straight down the cusp with little or no spiral effect (Figs 8D, 9B, 10A). As the diameter of the cusps increases proximally, additional cristae often originate away from the tip (Figs 9J, L; $11 \mathrm{G})$. In some cases, as many as half originate about one-fourth the cusp length from the tip, and an anastomosing pattern may occur. Because of this, coupled with the spiral effect and rather small size of the teeth, the number of cristae on any given cusp is not easily determined; nor are they easily illustrated (Fig. 8F, G).

The number of cristae per cusp does not change stratigraphically in the Wichita local faunas (Table 3), despite an increase in average tooth size through the section. Representative teeth selected for examination were chosen as possible candidates for illustrations. The number of cristae vary slightly with cusp size. The cusps of very small teeth $(\mathrm{am}-\mathrm{pl}=1 / 2-3 / 4 \mathrm{~mm})$ possess as many as 12 cristae, while slightly larger teeth $(\mathrm{am}-\mathrm{pl}=1 \mathrm{~mm})$ often have 14 or 15 cristae. Cusps of the largest teeth have about the same number, up to 18 cristae. Symphysial teeth (discussed below) have significantly fewer cristae than average. Teeth from the Dunkard Group localities have slightly fewer cristae per cusp, averaging about ten.

The cusps are more or less cylindrical in their distal half (Fig. 8E). They are increasingly more
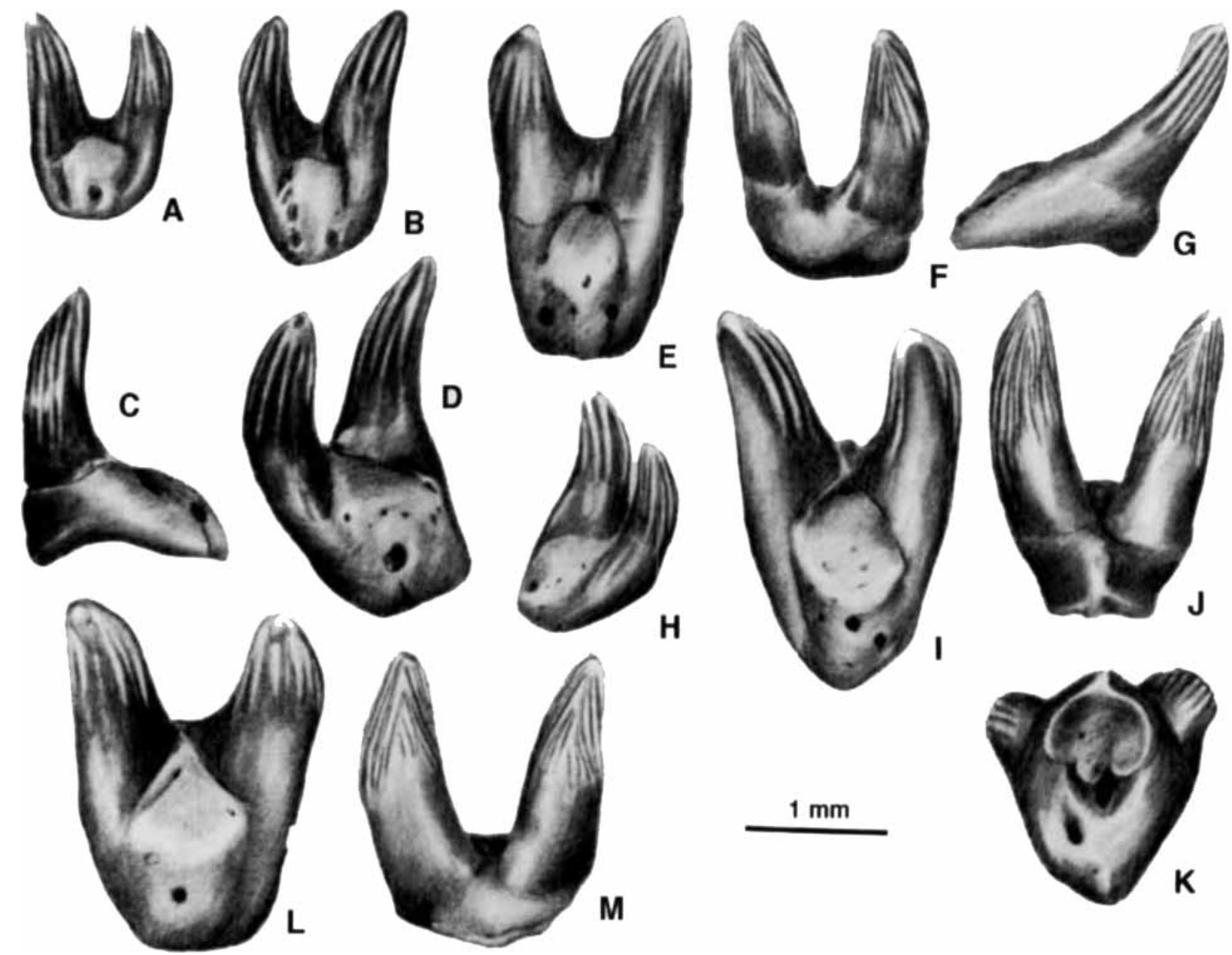

Fig. 9. Barbclabornia luedersensis (Berman, 1970). A-M, teeth from the Wolf Creek B local fauna, upper Belle Plains. A, lingual-occlusal view of SMU 64104; B, lingual-occlusal view of SMU 64106; C, anteromedial/posterolateral, and D, oblique lingual-occlusal views of SMU 64107; E, lingual-occlusal, F, labial, and G, anteromedial/posterolateral views of SMU 64109; H, oblique lingual-occlusal view of SMU 64108; I, lingual-occlusal, J, labial, and K, aboral views of SMU 64111; and L, lingual-occlusal, and M, labial views of SMU 64112. Modified from Johnson (1979: 457-458). 
compressed toward the base in their proximal half (Figs 8D, H; 9D; 10O; 11E, F.)

Symphysial teeth: The Barbclabornia luedersensis dentition does not demonstrate any distinctive heterodonty except for the presence of presumed symphysial teeth. Sixteen probable $B$. luedersensis symphysial teeth (SMU 6409264100 ) were selected from nine local faunas for study (Fig. 10C, D). These teeth are slightly smaller than average and have nearly vertical principal cusps that are very close together; the base is highly compressed in the am-pl direction and sometimes elongated in the $1-1$ direction. The most logical position for such a tooth would be at or adjacent to the jaw symphysis. The distribution of these teeth in the Wichita local faunas is inconsistent, however. In the larger local faunas, the rate of occurrence is about one in seven or eight hundred teeth. Single teeth of this type occurred in one local fauna (Brushy Creek M) that produced only four teeth and in another (Brushy Creek H) that produced only nine teeth. No symphysial teeth were found in the Wolf Creek local faunas (Table 1; Johnson 1979: 593-595) or in the Spring Creek B local fauna, but each contains several teeth that approach a similar morphology. It is not possible to determine if there is a gradational pattern emanating from the symphysis. If there is, then the teeth possessing the morphology described here along with the symphysial tooth should be termed medials, following Applegate's (1965) terminology. A few possible symphysial teeth are present in the Albany Group (Little Moonshine Creek local fauna).

Teeth with three cusps: Three teeth were found that possess an intermediate cusp in addition to the principal cusps. The first (SMU 64036), from the Mitchell Creek B local fauna, has both principal cusps broken. The distal end of the intermediate cusp has also been lost, so it cannot be determined whether or not it was cristated.
The second tooth (SMU 64058) is from the West Franklin Bend $\mathrm{C}$ local fauna. It is very small (1-1 dimension $=3 / 4 \mathrm{~mm}$ ), with the lingual tip of the base missing. The intermediate cusp is nearly two-thirds the length of the principal cusps (one distal end is missing), narrow, smooth, cylindrical in cross-section, and very prominent. The principal cusps bear about the normal number of cristae for a tooth this size. The third tooth (SMU 64088), from the Wolf Creek/ac local fauna, is abnormal (besides having a third reduced cusp originating from the labial side of the basal tubercle) and is described in Johnson (1987: 23).

Histology: Four teeth selected for thin-sectioning, with emphasis on the cusps (Fig. 12), are dominated by orthodentine (Smith \& Sansom 2000: 67) and show no evidence of change throughout the Wichita Group. The orthodentine is similar to that of Orthacanthus and Xenacanthus, and is unlike that of Triodus (Hampe 1991). The outer part of the base is composed of orthodentine (Fig. 12A), but trabecular dentine (Hampe 1991: pl. 4: 5, Hampe \& Heidtke 1997: fig. $6 \mathrm{D}, \mathrm{E})$ probably occurs in its interior (Fig. 12A, E). The interior is highly vascularized and is sharply offset from the cusp orthodentine (Fig. 12E).

The cusps contain a pulp cavity, and the orthodentine surrounding it is often covered by a clear layer of tissue into which the dentinal tubules slightly extend (Fig. 12C, K). No term for this marginal layer is universally accepted. Although Hampe (1991) preferred pallial dentine, this useage differs from the pallial dentine of Smith \& Sansom (2000: 67, fig. 5.2A), and should probably be avoided (Johnson 1981a: 2). Smith \& Sansom (2000) and Sander (2000: 93) use enameloid, apparently to maintain simplicity, but many object to its use because it implies the presence of crystallites, which are not present in xenacanth teeth (Reif 1977: 570, Hampe 1991, M. Richter, pers. comm.). Peyer's (1968: 65) description of vitrodentine (shiny outer zone of

Fig. 10. Barbclabornia luedersensis (Berman. 1970). A-B. tooth (SMU 64115) from the Hackberry Creek C local fauna, middle Clyde; A, lingual-occlusal and B. anteromedial/posterolateral views. C-D, possible symphysial tooth (SMU 64100) from the West Franklin Bend C local fauna, middle Clyde; C, nearly occlusal and D, anteromedial/posterolateral views. E-K, teeth from the West Franklin Bend C local fauna, middle Clyde; E, lingual, F, anteromedial/posterolateral, $\mathbf{G}$, labial, $\mathbf{H}$, lingual-occlusal, and I. aboral views of SMU 64116; J, anteromedial/posterolateral, and $\mathbf{K}$, lingual-occlusal views of SMU 64056 (the isolated appearance of the apical button is only apparent). $\mathbf{L}-\mathbf{R}$, teeth from the Spring Creek B/ac local fauna. upper Clyde; $\mathbf{L}$, anteromedial/posterolateral, and $\mathbf{M}$, oblique anteromedial/posterolateral-occlusal views of SMU 64028; and N, lingual-occlusal. $\mathbf{O}$. lingual. P, anteromedial/posterolateral, $\mathbf{Q}$, labial, and $\mathbf{R}$, aboral views of SMU 64101 (note the significant change of appearance caused by a slight rotation of the tooth from lingual-occlusal to lingual view). Modified from Johnson (1979: 457-460). 


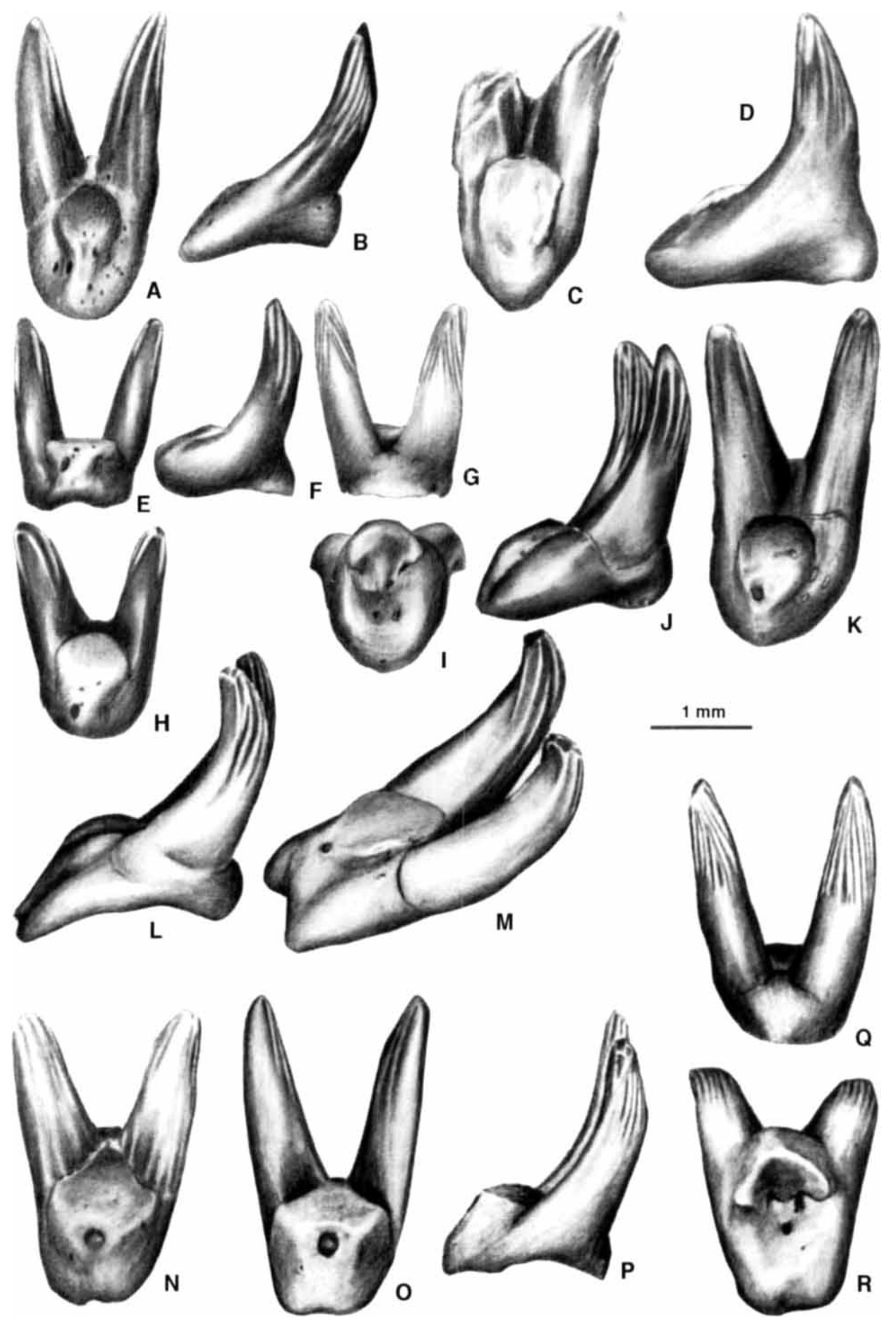




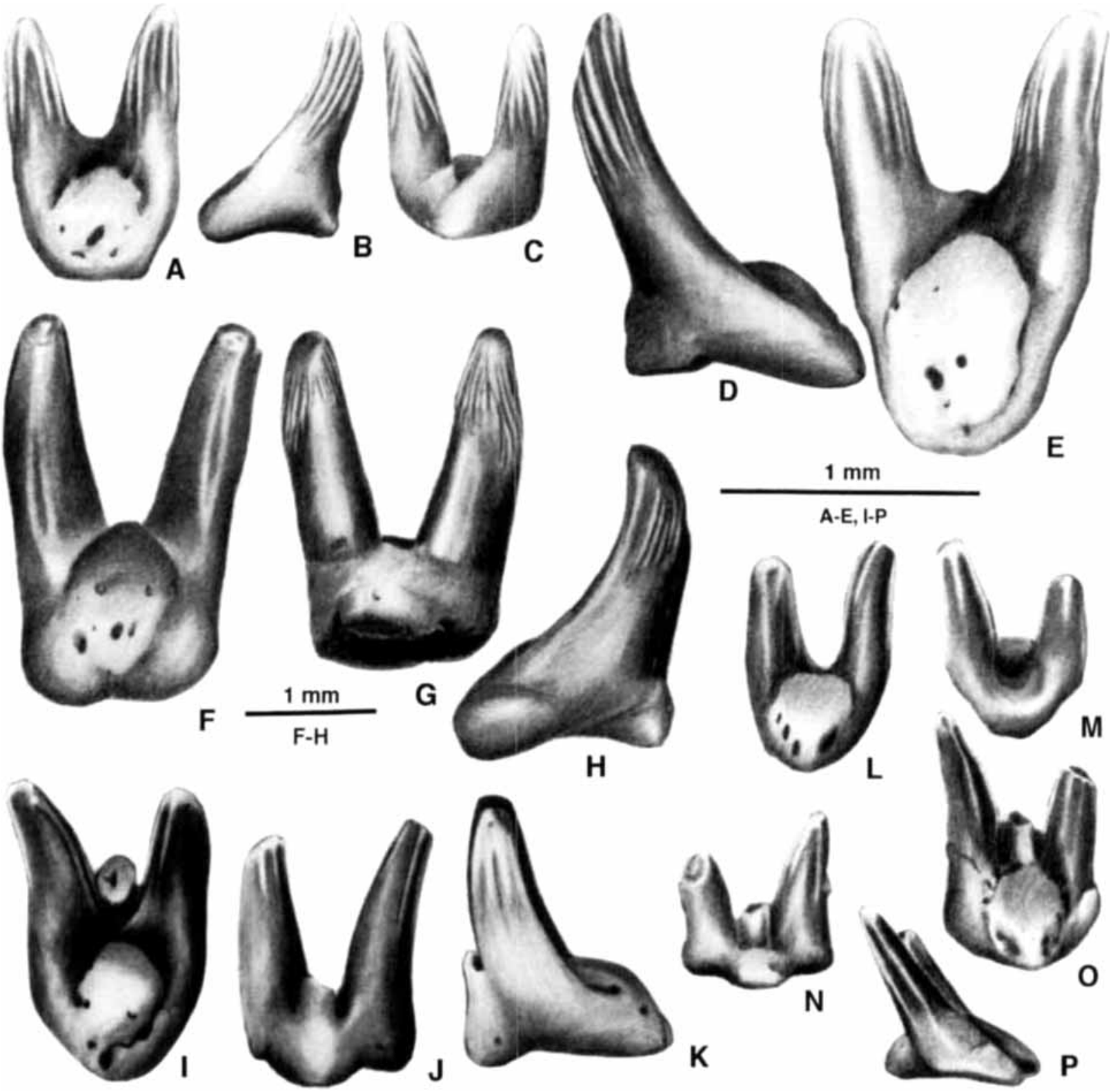

Fig. 11. A-H, Barbclabornia luedersensis (Berman. 1970). A-E. teeth from the Lake Kemp B local fauna, middle Lueders; A, lingual-occlusal, B, anteromedial/posterolateral, and C. labial views of SMU 64118; D, anteromedial/posterolateral, and E, lingual-occlusal views of SMU 64119; F. lingual-occlusal, G, aboral-labial, and $\mathbf{H}$, anteromedial/posterolateral views of SMU 64117 from the Lake Kemp B/ac local fauna, middle Lueders. I-P, aff. Barbclabornia. I-M, teeth from Site 2 (I-K) and Site $3(\mathbf{L}-\mathbf{M})$, Peru local fauna. Towle Shale; I, lingual-occlusal, J, labial, and $\mathbf{K}$, anteromedial/posterolateral views of TMM 41647-335; and $\mathbf{L}$, lingual-occlusal, and $\mathbf{M}$, labial views of TMM 41648-132. N, labial, $\mathbf{O}$, lingual-occlusal, and $\mathbf{P}$, anteromedial/posterolateral views of CM 35155 from the Kennard Playground local fauna, lower Pittsburgh Formation; the medial margin of the complete cusp and the adjacent margin of the apical button are obscured by matrix. From Johnson (1979: $461-462)$.

orthodentine with few dentinal tubules) seems to best fit the present observations. But objections to the use of vitrodentine have been influential (Ørvig 1967: 79, Poole 1967: 112). Poole (1967) suggested enameloid and Ørvig (1967) suggested "enameloid substance," which brings the argument full circle. Parallel to the present observations is Rieppel's (1981: 351) pallial dentine, which is restricted to the dentine-enameloid (strict sense) boundary in hybodont teeth.
Hampe \& Long (1999: 25) describe the base of Antarctilamna priscus as containing trabecular dentine and hypomineralized dentine with numerous interglobular spaces. They also state that the cristae-bearing zones of the cusps "...seem to show a differentiation of the outermost layer, in this case pallial dentine...", inferring a lack of dentinal tubules in the outer part of this differentiated layer. In their Fig. 3 (p. 26) they describe a "...peripheral zone of hypomineralized pallial 
dentine (cristae-bearing zone)..." They presumably meant for this peripheral zone to be hypermineralized pallial dentine. Employment and justification of a new term for the external layer in Barbclabornia teeth are beyond the scope of this discussion. Therefore, "hypermineralized pallial dentine" is presently used for this essentially atubular outermost layer, based on my interpretation of Hampe \& Long (1999: fig. 3). The thickness of this layer is variable, from nearly absent (Fig. 12H) to a maximum where a crista presumably occurs in the section (Fig. 12B, J). The layered appearance of the hypermineralized pallial dentine (Fig. 12C, K) is presumably an artifact of preservation.

Palatoquadrate: An incomplete large $(37.5 \mathrm{~cm}$ long) right palatoquadrate was recovered from the Lake Frederick locality (upper Garber Sandstone, =? Lower Clear Fork Group, Bill May, pers. comm.) in Oklahoma. According to Jiri Zidek (pers. comm.), hundreds of teeth are scattered in and ventral to the palatine dental groove; no intact tooth files can be discerned. However, the teeth show a consistent pattern in the changing shape of the base from anterior to posterior. Anteriorly positioned teeth have a more triangular shape to the base than the laterally and postlaterally positioned teeth with obliquely quadrangular shape, as seen in aboral view (Jiri Zidek, pers. comm.). Teeth similar to the presumed symphysial teeth described above are apparently absent, although the anterior end of the dental arcade may be missing (J. Zidek, pers. comm.). Based on the teeth, there is no doubt that this specimen belongs to Barbclabornia luedersensis.

Remarks: Perhaps the most distinctive feature of Barbclabornia teeth as well as Triodus and Bransonella teeth, for example, is the presence of cristae on the cusps. These teeth, with their cristated cylindrical cone-like cusps, present a marked contrast to the smooth, compressed cusps of Xenacanthus and Orthacanthus (most species bear serrated cusps, Johnson 1999). Whereas all other genera generally possess one or more intermediate cusps (Fig. 1B), except in some posterior teeth (Hampe 1988: 746-747, 1989: 94, Johnson 1999) and symphysial teeth (Hampe 1994: 72, 1997), the intermediate cusp is absent in Barbclabornia. However, it is present in its presumed most closely related species as discussed below. Stritzke (1986) described teeth lacking an intermediate cusp, but they were lost during preparation (see Stritzke 1986: fig. 2,
R. Soler-Gijón, pers. comm.). Hampe (1994: 67) states they are ctenacanthoid teeth, not xenacanthid.

If only the teeth from the Wichita Group and Albany Group were considered, one might infer an evolutionary trend in the general shape of the bases of Barbclabornia luedersensis teeth. This apparently is not true upon considering the Lake Frederick palatoquadrate and older Dunkard Basin teeth.

Several of the teeth from the West Franklin Bend C/ac local fauna have smooth cusps without cristae. This appearance results from part or all of the hypermineralized pallial dentine being stripped off, but the cause is unknown as abrasion is not apparent (Johnson 1979: 117-118).

The cusps are frequently broken in Barbclabornia luedersensis teeth. Typical xenacanths, as illustrated in various publications, may have cusps broken off at their base, but most are broken at various distances above their base. Contrary to this generality, the cusps in B. luedersensis teeth are mostly broken at the point where they join the tooth base (Johnson 1979: 236237).

Although the divergence of the principal cusps is slight in Barbclabornia luedersensis teeth, the most asymmetrical teeth (Fig. $8 \mathrm{M}$ ) probably occurred in the posterior portion of the arcade, anterior to those teeth with both cusps leaning toward the commissure (Fig. 8K). The pattern and number of cristae may also be controlled by tooth position in the arcade, but this would be very difficult to demonstrate.

The presumed symphysial teeth compare favorably with those of Triodus kraetschmeri (Hampe 1997: 127, fig. 6f-h). They lack an intermediate cusp, are compressed in the am-pl direction, and are smaller than normal. The comparison with Xenacanthus remigiusbergensis (Hampe 1994: 72, fig. 9f-h) is less favorable in the sense that its cusps are more divergent, besides differing in more obvious aspects. If only symphysial teeth were available for comparison, $T$. kraetschmeri and $B$. luedersensis teeth might be judged to be similar, based on Hampe's (1997) illustration. If symphysial teeth are present in Barbclabornia luedersensis, their presence does not significantly detract from considering the dentition to be homodont, relative to the heterodonty found in Orthacanthus teeth (Johnson 1999).

There is little doubt the three teeth with an intermediate cusp belong to Barbclabornia luedersensis. It is most likely an atavistic feature, and they are as uncommon as deformed teeth 

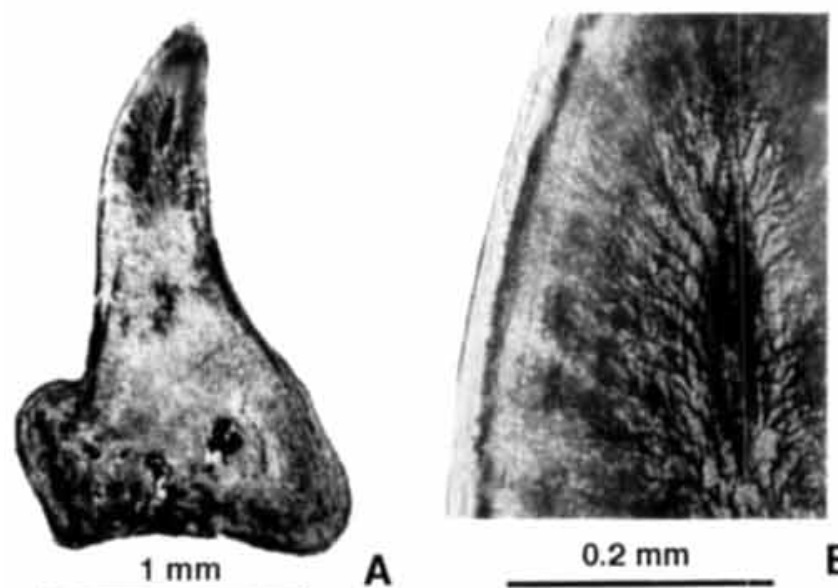

A

$0.2 \mathrm{~mm}$
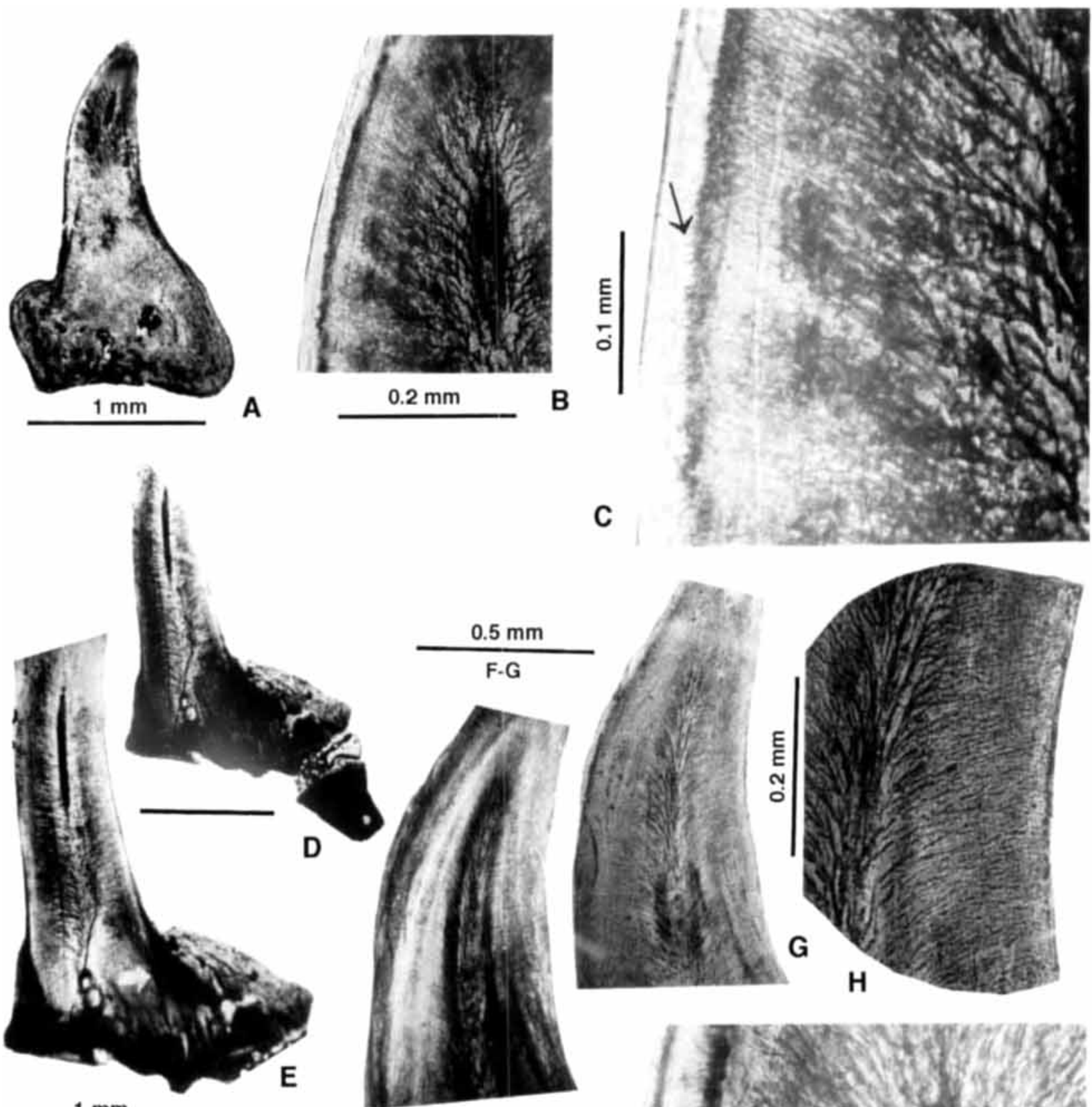

C

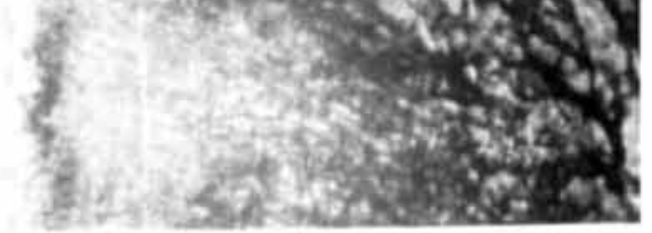

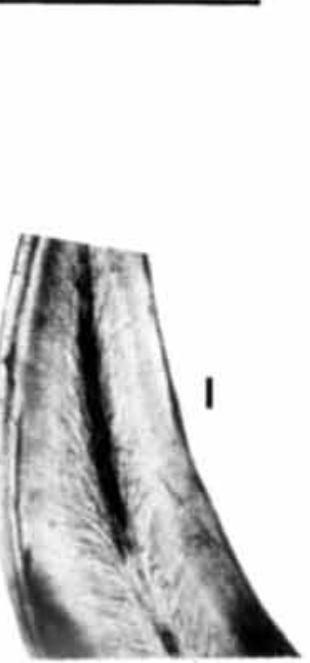

$0.5 \mathrm{~mm}$

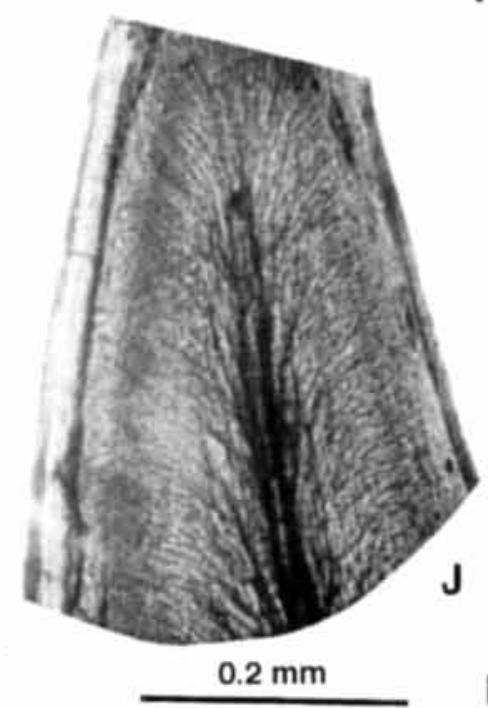

$\mathbf{F}$

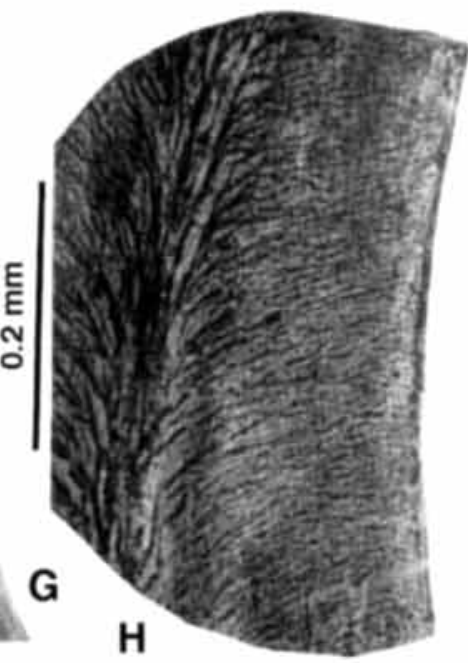

H

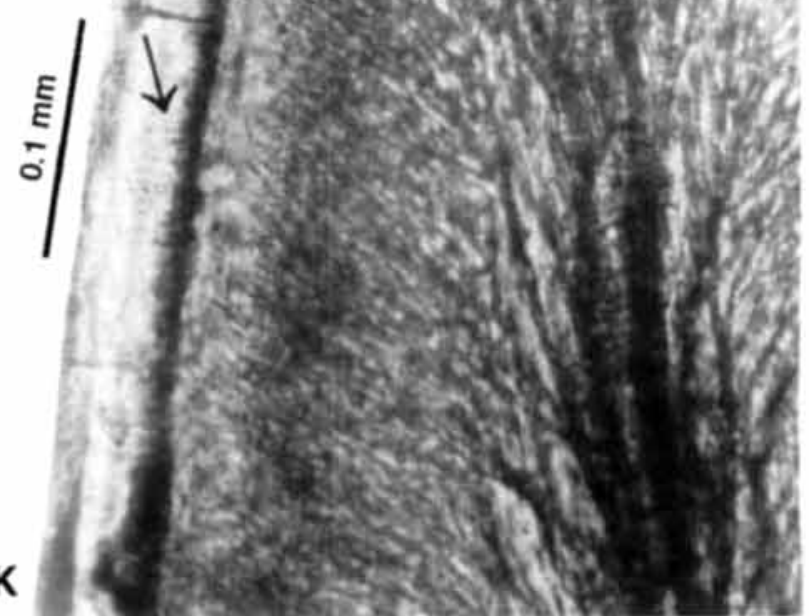


(Johnson 1987). But the presence of a separate species cannot be ruled out. These teeth certainly compare less favorably with Triodus $(X$.) moorei (Johnson, 1980) than with $B$. luedersensis, for example, and they are not similar to aff. Barbclabornia teeth described below.

\section{Barbclabornia cf. $B$. luedersensis}

Figs 2, 3, 13, 14; Tables 1, 2

The youngest Barbclabornia teeth (SMU 68811, 69157-69161) known from Texas occur in the nearly lowermost part of the Clear Fork Group (lower "Arroyo Formation" Murry \& Johnson
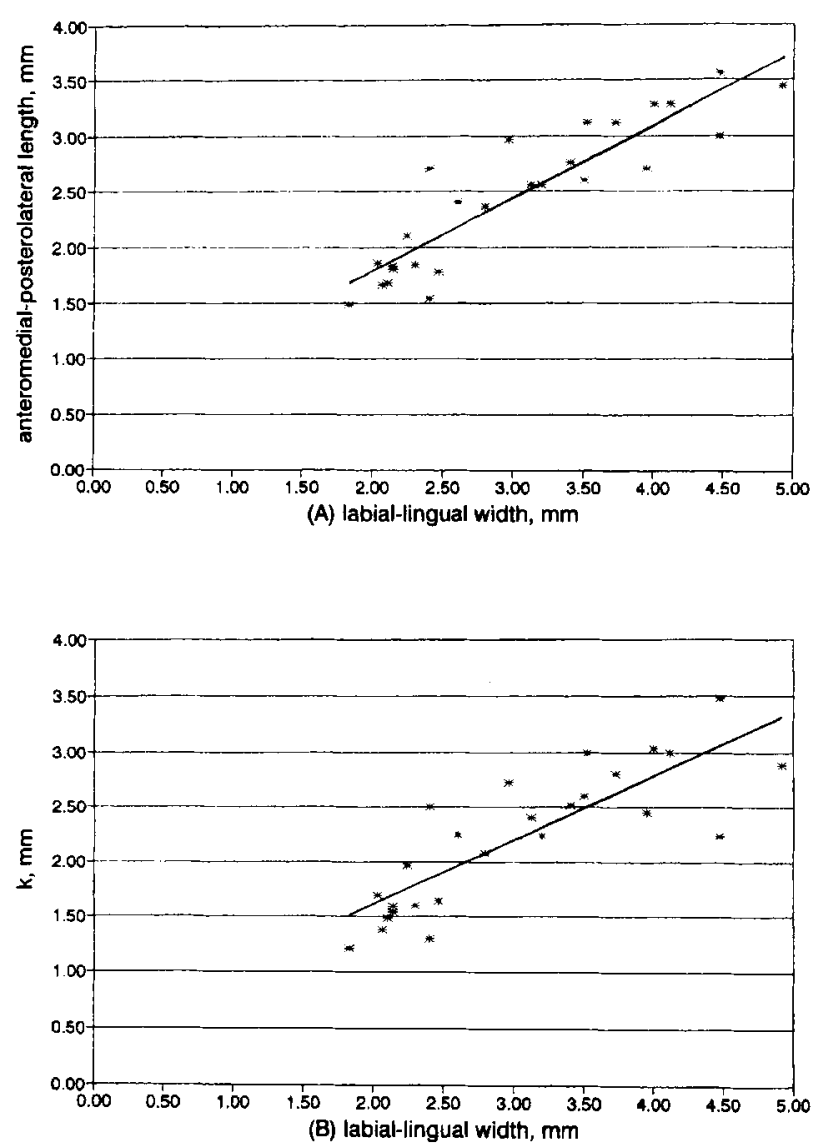

Fig. 13. Scatter diagrams of tooth-base measurements of Barbclabornia cf. B. luedersensis teeth from the East Coffee Creek 47 local fauna, lower Arroyo. Lines represent the linear regressions of the am-pl dimension on the l-1 dimension (A) and the $\mathrm{k}$ dimension on the 1-l dimension (B); see Table 2 and Fig. 2. For an explanation of $\mathbf{k}$, see text and Fig. 1.
1987; lower part of informal Red Tank sandstone member of Nelson et al. 2001, R. Hook, pers. comm.). The teeth are similar to $B$. luedersensis, except the base is much more robust and always quadrangular in shape. The lingual margin of the base is straight and the labial margin of the base sometimes extends beyond the labial margin of the basal tubercle. Cristae are absent on the lingual margin.

The only distinctive feature of these teeth is the robust or inflated appearance of the base (Fig. 14) relative to Barbclabornia luedersensis. Measurements of the base (Table 2, Figs 2B, 3, 13) reflect this inflation, and the slope of the linear regression (Fig. 2A) demonstrates a persistently greater $\mathrm{l}-\mathrm{l}$ width than am-pl length with few exceptions (Fig. 13A). There is little difference between the am-pl and $\mathrm{k}$ dimensions (Fig. 3), reflecting the generally quadranglar shape of larger Barbclabornia teeth.

Cristae are restricted to the distal half of the cusps. Only a trace of one crista occurs on the illustrated tooth (Fig. 14C). On the few cusps that are preserved, 14 to 18 or 20 cristae are present plus a few more proximally shorter ones. The coarsest cristae are on the medial and am-pl margins. The cusps are composed of orthodentine (Fig. 14F); hypermineralized pallial dentine is presumably present in the cristae.

None of the teeth possess a bifurcated lingual margin on the base. Otherwise, these teeth have a base similar to Barbclabornia luedersensis regarding the number and pattern of the foramina, and the apical button. In some instances the inflated basal tubercle does not have a well defined articulating surface (contact with the succeeding apical button in the tooth file) which reduces the accuracy of the $1-1$ measurement (Johnson 1979: 92).

As both principal cusps are not intact in any of the available teeth, their attitude is unknown. Evidence from the few intact proximal ends suggests no difference from $B$. luedersensis.

Remarks: Barbclabornia cf. B. luedersensis teeth are restricted to the base of the Clear Fork Group (Murry \& Johnson 1987, Johnson 1996: fig. 5). Although there is considerable overlap in

Fig. 12. Thin sections of Barbclabornia luedersensis (Berman, 1970) teeth. A-C, successive enlargements of SMU 68807 from the Brushy Creek I local fauna. D-H, teeth from the Hackberry Creek C local fauna; D-E, SMU 68809 (the lingual tip of the base in D is not displaced, but the result of the plane of the section passing through a vascular canal; the arrow in $E$ indicates the cusp-base boundary); $\mathbf{F}-\mathbf{H}$, SMU 68808 ( $\mathrm{H}$ is an enlarged portion of $\mathrm{G}$ ). I-K, successive enlargements of SMU 68810 from the Lake Kemp A local fauna. Arrows in $\mathrm{C}$ and $\mathrm{K}$ indicate dentinal tubules extending into the hypermineralized pallial dentine. Ordinary light, except polarized light in E, F, and I. 
Table 1

List of local faunas containing Barbclabornia (n. gen.) teeth obtained by bulk sampling. Compare with Table 1 in Johnson (1999). Stratigraphic order is maintained as closely as possible. Numbers following the Clear Fork, Albany, and Wichita local fauna names are SMU locality numbers. Numbers in parentheses following the Wichita locality numbers are thicknesses in meters from the Belle Plains-Clyde contact (uncertain for Lake Electra/ac and especially Bluff Creek local faunas; horizons estimated from field notes and Hentz \& Brown 1987). Permian stratigraphic nomenclature in Texas based on Johnson (1979, Wichita Group) and Johnson (1996, Albany Group) with approximate equivalent names based on Hentz (1988) in parentheses, and on Murry \& Johnson (1987, Clear Fork Group). Dunkard Basin stratigraphic nomenclature based on CMNH catalogue data, modified by U.S. Geological Survey stratigraphic nomenclature where possible. Sample sizes vary considerably; see Johnson (1979, Wichita Group; 1996, Albany Group) and Murry \& Johnson (1987, Clear Fork Group); sample size unknown for Peru and Dunkard Basin local faunas.

\begin{tabular}{lll}
\hline $\begin{array}{l}\text { B. } \\
\text { lueders- } \\
\text { ensis }\end{array}$ & $\begin{array}{l}\text { lueders- } \\
\text { ensis }\end{array}$ \\
\hline
\end{tabular}

\section{LOWER PERMIAN}

Clear Fork Group (Artinskian), Texas

lower Arroyo

East Coffee Creek 47

East Coffee Creek 39

East Coffee Creek 38

East Coffee Creek 37

East Coffee Creek 36

Albany Group (Artinskian). Texas

upper Lueders Formation

Little Moonshine Creek 268

Wichita Group (Artinskian). Texas

middle Lueders (1. upper Waggoner Ranch)

Southwest Butte/ac $343(+88 \mathrm{~m})$

Tit Butte/ac $344(+88 \mathrm{~m})$

Lake Kemp B $345(+87 \mathrm{~m}) \quad 143$

Lake Kemp B/ac 345 (+87 m)

Lake Kemp A $340(+86 \mathrm{~m}) \quad 170$

Lake Electra/ac 346

lower Lueders (u. mid. Waggoner Ranch)

Mitchell Creek H $347(+72 \mathrm{~m})$

Mitchell Creek G $348(+70 \mathrm{~m})$

Mitchell Creek F/ac $349(+67 \mathrm{~m})$

upper Clyde (mid. Waggoner Ranch)

Mitchell Creek E $350(+60 \mathrm{~m})$

Mitchell Creek E/ac $350(+60 \mathrm{~m})$

Mitchell Creek D $351(+60 \mathrm{~m})$

Mitchell Creek C $352(+59 \mathrm{~m})$

Mitchell Creek B $160(+56 \mathrm{~m})$

Mitchell Creek B/ac $160(+56 \mathrm{~m})$

Mitchell Creek A $353(+56 \mathrm{~m})$

Bluff Creek C 354

Bluff Creek B 355

Bluff Creek A 356

Spring Creek B/ac $357(+53 \mathrm{~m})$

La Paloma/ac $358(+50 \mathrm{~m})$

Spring Creek A/ac $359(+48 \mathrm{~m})$

Spring Creek/ac $360(+48 \mathrm{~m})$

Old Military Crossing $361(+44 \mathrm{~m})$

middle Clyde (1. mid. Waggoner Ranch)

West Franklin Bend C $286(+40 \mathrm{~m})$

West Franklin Bend C/ac $286(+40 \mathrm{~m})$

Hackberry Creek C $339(+37 \mathrm{~m})$

West Franklin Bend B/ac $362(+36 \mathrm{~m})$

West Franklin Bend A/ac $363(+34 \mathrm{~m})$

Hackberry Creek B $364(+32$ m)

Hackberry Creek A/ac $365(+32$ m)

Franklin Bend A/ac $366(+24 \mathrm{~m})$

Franklin Bend A $366(+24 \mathrm{~m})$

lower Clyde (lower Waggoner Ranch)

Cottonwood Creek $367(+6 \mathrm{~m})$

Brushy Creek O $368(+2 \mathrm{~m})$

Brushy Creek N $369(+1 \mathrm{~m})$

upper Belle Plains (upper Petrolia)

Wolf Creek B/ac $285(-8 \mathrm{~m})$

Wolf Creek B $285(-8 \mathrm{~m})$

\begin{tabular}{lrl}
\hline & $\begin{array}{l}\text { B. } \\
\text { lueders- } \\
\text { ensis }\end{array}$ & $\begin{array}{l}\text { B. cf. } \\
\text { ensis }\end{array}$ \\
\hline Wolf Creek A 285 $(-8 \mathrm{~m})$ & 317 \\
Wolf Creek/ac 285 $(-8 \mathrm{~m})$ & 796 \\
Brushy Creek M/ac 370 $(-9 \mathrm{~m})$ & 4 \\
Brushy Creek L/ac 371 $(-10 \mathrm{~m})$ & 8 \\
Brushy Creek K/ac 372 (-10 m) & 106 \\
Brushy Creek J/ac 373 $(-10 \mathrm{~m})$ & 160 \\
Brushy Creek I 338 $(-10 \mathrm{~m})$ & 1073 \\
Brushy Creek H 338 $(-10 \mathrm{~m})$ & 9 \\
Brushy Creek G 374 $(-11 \mathrm{~m})$ & 0 \\
Brushy Creek F 276 $(-11 \mathrm{~m})$ & 5 \\
Brushy Creek E 375 $(-12 \mathrm{~m})$ & 3 \\
Brushy Creek D 376 $(-12 \mathrm{~m})$ & 1 \\
Brushy Creek C 377 $(-12 \mathrm{~m})$ & 94 \\
Brushy Creek C/ac 377 (-12 m) & 167 \\
Brushy Creek B 378 $(-12 \mathrm{~m})$ & 0 \\
upper Admiral (u. Nocona; Sakmarian) & \\
Rattlesnake Canyon 284 (?-100 m) & 2
\end{tabular}

Dunkard Group (Asselian-Sakmarian), Dunkard Basin

Greene Formation

Windy Gap Limestone

Fairview Ridge

upper Greene

Postlewaithe Ridge

lower Rockport Member Dallas Pike

lower Greene Belpre

Washington Formation

upper Washington

Powhatan Point

Waynesburg Formation

Colvin Limestone

Franklin Mall

88

UPPER PENNSYLVANIAN

Admire Group (Gzhelian), Nebraska

Towle Shale

Peru Site 2

Peru Site 3

Monongahela Group (Gzhelian),

Dunkard Basin

Pittsburgh Formation

lower Pittsburgh limestone

Kennard Playground

Conemaugh Group (Gzhelian),

Dunkard Basin

Conemaugh Formation

Duquesne Limestone bed No. 6 Fort Pitt Tunnel-6

Duquesne Limestone bed No. $2 \mathrm{~A}$ Fort Pitt Tunnel-2A

$0^{1.2}$
1 Barbclabornia aff. luedersensis, see text. 
Table 2

Summary of Barbclabornia (n. gen.) tooth measurements (in millimetres). $\mathrm{N}$ and $\mathrm{n}$ are the number of teeth in the local fauna and sample, respectively; $\mathrm{m}$ and $\mathrm{b}$ are the slope and $\mathrm{y}$-intercept, respectively; other abbreviations defined in text; (b) from Johnson (1996) and (c)-(j) from Johnson (1979: 109). *data from this sample used to represent (e) in Figs 2 and 3 : **first line represents regression of am-pl on $1-1$, second line, $\mathrm{k}$ on $1-1 ; 95 \%$ confidence intervals determined by method given in Simpson et al. (1960: 224-229). The means in local faunas (f) and (h) are slightly biased; $k$ not determined for (b); see text. $\mathrm{N}$ includes MB. teeth $(e, h)$ and thin-sectioned teeth $(a, h)$; values differ from Table 1 .

\begin{tabular}{|c|c|c|c|c|c|c|c|c|c|c|c|}
\hline \multirow[t]{2}{*}{ Local } & \multirow[t]{2}{*}{1 Fauna } & \multirow[t]{2}{*}{$\mathrm{N}$} & \multirow[t]{2}{*}{$\mathrm{n}$} & \multicolumn{3}{|l|}{ Range } & \multicolumn{3}{|c|}{ Mean \pm 1 s. d. } & \multicolumn{2}{|c|}{ Linear Regression** } \\
\hline & & & & $1-1$ & am-pl & $\mathrm{k}$ & $1-1$ & am-pl & k & $\mathrm{m}$ & b \\
\hline \multicolumn{12}{|c|}{ B. cf luedersensis } \\
\hline (a) & $\begin{array}{l}\text { East Coffee } \\
\text { Creek } 47\end{array}$ & 30 & 26 & $1.83-4.92$ & $1.48-3.56$ & $1.21-3.48$ & $3.03 \pm .90$ & $2.46 \pm .65$ & $2.22 \pm .63$ & $\begin{array}{l}0.65 \pm .13 \\
0.59 \pm .16\end{array}$ & $\begin{array}{l}+0.49 \pm .41 \\
+0.44 \pm .52\end{array}$ \\
\hline \multicolumn{12}{|c|}{ B. luedersensis } \\
\hline (b) & $\begin{array}{l}\text { Little Moon- } \\
\text { shine Creek }\end{array}$ & 591 & 99 & $1.13-3.56$ & $0.89-3.12$ & & $2.15 \pm .58$ & $1.75 \pm .53$ & & $0.81 \pm .08$ & $0.00 \pm .19$ \\
\hline (c) & Tit Butte/ac & 114 & 35 & $0.69-2.23$ & $0.52-1.71$ & $0.43-1.61$ & $1.14 \pm .37$ & $0.97 \pm .31$ & $0.83 \pm .33$ & $\begin{array}{l}0.81 \pm .10 \\
0.82 \pm .11\end{array}$ & $\begin{array}{l}+0.05 \pm .12 \\
-0.10 \pm .13\end{array}$ \\
\hline (d) & $\begin{array}{l}\text { Lake } \\
\text { Kemp B }\end{array}$ & 143 & 42 & $0.74-2.77$ & $0.62-2.40$ & $0.55-2.40$ & $1.86 \pm .62$ & $1.50 \pm .50$ & $1.42 \pm .51$ & $\begin{array}{l}0.76 \pm .08 \\
0.76 \pm .09\end{array}$ & $\begin{array}{l}+0.08 \pm .15 \\
-0.01 \pm .17\end{array}$ \\
\hline (e1) & $\begin{array}{l}\text { Mitchell } \\
\text { Creek B/ac }\end{array}$ & 6452 & 98 & $0.69-3.20$ & $0.62-3.01$ & $0.60-2.88$ & $1.75 \pm .46$ & $1.53 \pm .41$ & $1.34 \pm .40$ & $\begin{array}{l}0.83 \pm .07 \\
0.78 \pm .08\end{array}$ & $\begin{array}{l}+0.08 \pm .12 \\
-0.03 \pm .14\end{array}$ \\
\hline$\left(\mathrm{e} 2^{*}\right)$ & $\begin{array}{l}\text { Mitchell } \\
\text { Creek B/ac }\end{array}$ & & 96 & $0.78-3.20$ & $0.66-2.88$ & $0.50-2.81$ & $1.84 \pm .46$ & $1.58 \pm .40$ & $1.39 \pm .38$ & $\begin{array}{l}0.82 \pm .07 \\
0.76 \pm .07\end{array}$ & $\begin{array}{l}+0.07 \pm .13 \\
-0.01 \pm .14\end{array}$ \\
\hline (e3) & $\begin{array}{l}\text { Mitchell } \\
\text { Creek B/ac }\end{array}$ & & 95 & $0.81-3.00$ & $0.52-2.64$ & $0.43-2.33$ & $1.92 \pm .53$ & $1.66 \pm .44$ & $1.46 \pm .42$ & $\begin{array}{l}0.76 \pm .06 \\
0.71 \pm .07\end{array}$ & $\begin{array}{l}+0.20 \pm .13 \\
+0.10 \pm .14\end{array}$ \\
\hline (f) & $\begin{array}{l}\text { Hackberry } \\
\text { Creek C }\end{array}$ & 1013 & 98 & $0.69-2.91$ & $0.66-2.40$ & $0.55-2.23$ & $1.71 \pm .41$ & $1.43 \pm .30$ & $1.24 \pm .30$ & $\begin{array}{l}0.67 \pm .07 \\
0.65 \pm .07\end{array}$ & $\begin{array}{l}+0.29 \pm .12 \\
+0.13 \pm .13\end{array}$ \\
\hline (g) & $\begin{array}{l}\text { Wolf } \\
\text { Creek/ac }\end{array}$ & 796 & 89 & $0.43-1.78$ & $0.34-1.40$ & $0.33-1.24$ & $1.19 \pm .27$ & $0.97 \pm .19$ & $0.82 \pm .18$ & $\begin{array}{l}0.56 \pm .09 \\
0.52 \pm .09\end{array}$ & $\begin{array}{l}+0.30 \pm .10 \\
+0.20 \pm .11\end{array}$ \\
\hline (h) & $\begin{array}{l}\text { Brushy } \\
\text { Creek I }\end{array}$ & 1085 & 98 & $0.62-1.66$ & $0.50-1.29$ & $0.41-1.09$ & $1.08 \pm .24$ & $0.89 \pm .17$ & $0.70 \pm .13$ & $\begin{array}{l}0.59 \pm .08 \\
0.39 \pm .08\end{array}$ & $\begin{array}{l}+0.25 \pm .09 \\
+0.28 \pm .08\end{array}$ \\
\hline (i) & $\begin{array}{l}\text { Powhatan } \\
\text { Point }\end{array}$ & 45 & 40 & $0.57-1.45$ & $0.59-1.14$ & $0.52-1.00$ & $0.95 \pm .21$ & $0.86 \pm .16$ & $0.73 \pm .14$ & $\begin{array}{l}0.65 \pm .14 \\
0.43 \pm .18\end{array}$ & $\begin{array}{l}+0.25 \pm .13 \\
+0.32 \pm .17\end{array}$ \\
\hline (j) & $\begin{array}{l}\text { Franklin } \\
\text { Mall }\end{array}$ & 72 & 61 & $0.41-0.97$ & $0.34-0.95$ & $0.29-0.91$ & $0.64 \pm .12$ & $0.60 \pm .12$ & $0.53 \pm .12$ & $\begin{array}{l}0.86 \pm .12 \\
0.80 \pm .14\end{array}$ & $\begin{array}{l}+0.05 \pm .08 \\
+0.02 \pm .09\end{array}$ \\
\hline
\end{tabular}

size with $B$. luedersensis teeth from the subjacent Little Moonshine Creek local fauna (Table 2, Fig. 3), the lack of smaller teeth above the Albany (or Wichita)-Clear Fork boundary suggests speciation may have occurred in the Albany-Clear Fork transition (compare Fig. 13A with Johnson 1996: fig. 4). Johnson (1996: 380) asserted that only a size increase occurred and that $B$. (' $X$.') luedersensis continued into the Clear Fork Group. The differences in the slopes and y-intercepts (Fig. 2, Table 2) between the upper Wichita (and Albany) and Clear Fork samples, are not statistically significant. The inflated appearance of the Clear Fork tooth base and concomitantly larger cusps, however, suggest the existence of a new species. The lack of a bifurcated lingual margin of the base in any of the Clear Fork teeth suggests this is a trait restricted to some of the $B$. luedersensis teeth and is not a feature generally associated with larger Barbclabornia teeth. The small number of Clear Fork teeth (Table 1) and lack of complete teeth is a hindrance in assessing their correct identity.
If there were not a stratigraphic boundary between the Little Moonshine Creek fauna and East Coffee Creek faunas (Table 1), would there still be an inclination to suspect the identity of these teeth? Orthacanthus platypternus (Johnson 1999) spans the Wichita-Albany and Clear Fork Groups, but several other shark species do not cross the boundary (Johnson 1996: fig. 5, 1999: table 1). It therefore seems that Barbclabornia was "fortunate" to survive the boundary crossing.

\section{Teeth with affinities to Barbclabornia}

Fig. 11I-P

Three teeth (TMM 41647-335; 41648-132,-143) from the Peru locality in southeastern Nebraska (Table 1) are similar to Barbclabornia luedersensis but exhibit two or three differences. Although the apical button does not extend between the principal cusps, it is still in contact with them. A central foramen apparently is present but obscured by matrix. An intermediate cusp is pre- 


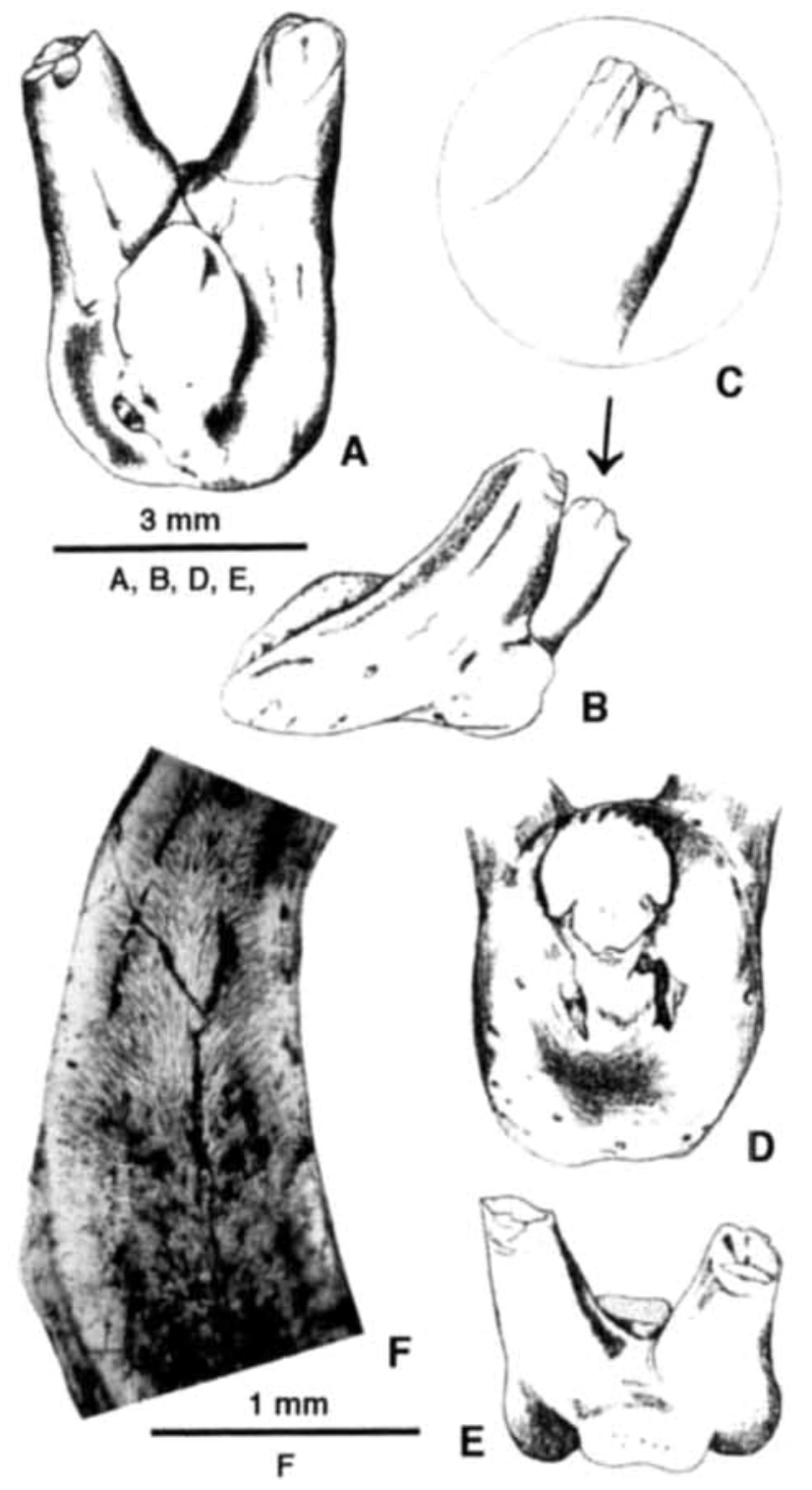

Fig. 14. Barbclabornia cf. B. luedersensis teeth from the East Coffee Creek 47 local fauna, lower Arroyo. A, lingualocclusal and $\mathbf{B}$, anteromedial/posterolateral views, $\mathbf{C}$, enlarged medial surface of cusp (deliberately enhanced to show the trace of the proximal end of a crista), and D, aboral. and E, labial views of SMU 69157. F, thin section of SMU 68811 (polarized light); both margins are complete, and there is interference from weathering and matrix; section is thicker than normal.

sent (completely broken away in TMM 41648-132, Fig. 11L, M), occurring slightly labial to the principal cusps (Fig. $11 \mathrm{~K}$ ). The principal cusps have fewer cristae than in B. luedersensis. Six typically occur on a cusp and are essentially limited to the distal half, with the exception that one medial crista extends nearly the full length; all are nearly straight.

Lund (1970) briefly described Xenacanthus teeth from his Duquesne Limestone No. 6 (Virgilian $=$ Gzhelian, Table 1) in the Dunkard Basin as having six to eight cristae per principal cusp.
Table 3

Estimated numbers of cristae on the cusps of Barbclabornia luedersensis teeth from the Lueders Formation (Albany Group; Johnson 1996) and Wichita Group of Texas (Johnson 1979: 116). $\mathbf{N}=$ number of cusps examined, $\mathbf{M}=$ mean, $\mathbf{R}=$ range

\begin{tabular}{lllr}
\hline & & \multicolumn{2}{c}{ Cristae/cusp } \\
& $\mathbf{N}$ & $\mathbf{M}$ & $\mathbf{R}$ \\
\hline & Lueders \\
& Formation & & \\
Lake Kemp B, B/ac & 6 & 12.0 & $11-14$ \\
& Wichita Group & & \\
& Clyde & & \\
Spring Creek B & 18 & 13.3 & $9-16$ \\
Spring Creek A & 7 & 15.1 & $12-18$ \\
West Franklin Bend C, C/ac & $8^{1}$ & 11.1 & $8-15$ \\
Hackberry Creek & $5^{2}$ & 13.2 & $10-16$ \\
Franklin Bend A/ac & 8 & 14.2 & $13-15$ \\
& Belle Plains & & \\
Wolf Creek B & 27 & 14.1 & $11-18$ \\
Brushy Creek J & 21 & 12.1 & $9-16$ \\
Brushy Creek I & 18 & 14.3 & $11-18$ \\
$\quad$ 1.2 Includes 2 and 1 cusps, & respectively, from symphysial \\
teeth; see text. & & &
\end{tabular}

An intermediate cusp is present, about one half the length of the principal cusps. For unexplained reasons, he later (1976: 232) considered these teeth as $X$. gracilis, which they cannot be (Hotton 1952, Johnson 1979: 258-259; examination of UF528 at Field Museum of Natural History, Chicago). They should probably be considered as aff. Barbclabornia even if they are not identical to the Peru specimens; or they may be a species of Triodus (or cf. Triodus). Teeth labeled as Xenacanthus gracilis (Lund 1976) or Xenacanthus sp. from DL6 (Lund 1970) could not be located in the Carnegie Museum collections. The teeth Lund (1976: 234) considered as Xenacanthus cf. $X$. luedersensis do belong to $B$. luedersensis.

A very small tooth (Fig. $11 \mathrm{~N}-\mathrm{P}$ ) from a lower Pittsburgh Limestone (Gzhelian) locality in Pittsburgh. Pennsylvania (Table 1), also has an affinity with Barbclabornia. It is different from the teeth described above in that the tooth base has an appearance similar to that of Orthacanthus compressus teeth (Johnson 1999), except that the apical button is nearly in contact with the intermediate cusp. The principal cusps are slightly diverging, cristated (4/cusp?), and more cylindrical than compressed in the distal portion; the major transverse axes of the proximal portion approaches the attitude of the cusps in Barbclabornia (Fig. 1D). The central foramen, if present, is obscured by matrix. Despite these features, this 
tooth can be mistaken for an $O$. aff. compressus tooth (Johnson 1999: 250). Although it is more like a Barbclabornia tooth than an Orthacanthus tooth, direct comparison of this tooth with the three teeth from the Peru locality shows a considerable difference in their bases. The main exception is that the apical button is not isolated from the principal cusps (Fig. 1). This feature was considered by Johnson (1979: 269) to be of fundamental importance in xenacanth taxonomy.

Remarks: Because Triodus teeth are more similar to Barbclabornia than those of any other described genus, then $B$. luedersensis is probably most closely related to a species of Triodus from the Pennsylvanian that possessed a tooth base similar to Barbclabornia (Fig. 1D) in which a central foramen might be absent (although a central foramen may always be associated with an intermediate cusp; R. Soler-Gijón, pers. comm.). It is further assumed that this species would have been closely related to an ancestor of T. (X.) moorei (Johnson 1980). The teeth described by Lund (1970; see above) might serve as a candidate if they are not aff. Barbclabornia. The stratigraphic isolation of $T$. $(X$.$) moorei re-$ mains unexplained. Its ancestor should be expected in the Lower Permian, because teeth very similar to $T$. (X.) moorei occur in the Paraná Basin of Brazil (questionably from Permian strata [otherwise from the Triassic], Evaldo Wehmuth Ragonha, pers. comm., March 1985).

\section{Habitat of Barbclabornia}

Berman (1970) suggested that Barbclabornia luedersensis may be a marine species, mainly because of its then unique occurrence in the Lueders, which is partly marine (Johnson 1996: fig. 2). Johnson (1992b) also suggested the possibility of a marine habitat because of its absence from a prolific freshwater fauna (Sander 1989; see Occurrence above) in the Bowie Group below the Wichita Group. However, Barbclabornia very likely inhabited fresh water. Berman considered both his localities (Tit Butte and Lake Kemp $B$ and $B / a c$ in this study) as nearshore marine, although he invokes a direct influence of discharging freshwater streams at Tit Butte. The limeclasts in the fossiliferous layer at Tit Butte (Berman 1970: 10-15) suggest deposition by one or more storm surges, similar to that described by Parrish (1978: 230-232; see also Hentz 1988: 39-41). The depositional environment of the clay-pebble conglomerate containing the Lake Kemp B and B/ac faunas (Berman's Site 2), which contains tetrapods (Johnson 1979: 627-628), remains uncertain as explained by Berman (1970: 15). All the Wichita local faunas probably occur in coastal-plain or nearshore deposits, based on the presence of thin marine carbonates; nearly all contain $B$. luedersensis teeth as well as tetrapod elements (Johnson 1979: 580-632). Although some of the tetrapods (temnospondyl amphibians) may have been saltwater tolerant (Sequeira 1998: 256-257, Laurin \& Soler-Gijón 2001), many, such as the pelycosaurian reptiles, were definitely terrestrial (Olson 1971: 645-651). The most prolific faunas cannot be demonstrated to be exclusively terrestrial (floodplain facies), as in most of the lower to middle Clear Fork Group deposits (Nelson et al. 2001), for example. But many of these Wichita faunas are not in close proximity to marine carbonates (Johnson 1979: 580-632), and the Wichita facies are dominantly freshwater (Hentz 1988).

The restricted occurrence of Barbclabornia cf. $B$. luedersensis in the basal Clear Fork, which may have been a coastal plain (Murry \& Johnson 1987), might strengthen the argument for a marine affinity. However, it is present in presumably freshwater tetrapod-bearing facies $25 \mathrm{~km}$ northeast of the Coffee Creek localities where marine limestones are absent from the WichitaClear Fork boundary (Hentz \& Brown 1987) (study in progress), and it is absent from the marine facies of the Arroyo Formation in Central Texas (Olson 1989). Also, B. cf. luedersensis teeth do not occur in the very lowermost facies of the Clear Fork that includes the intertidal to supratidal Craddock dolomite bed (informal) of Nelson et al. (2001); they are found in the meandering-channel deposits of the overlying Red Tank sandstone member (informal), which is the most fossiliferous (vertebrates and plants) unit of the lower Clear Fork (Nelson et al. 2001).

Both Barbclabornia luedersensis and Orthacanthus texensis (Johnson, 1999) could have been brackish-water or nearshore marine inhabitants, but their relative abundances in the various Wichita local faunas fail to show a consistent pattern (Johnson 1979: 231-233). There is evidence that $O$. texensis probably was a coastal dweller at least part of the time (Johnson, 1999: 254), and may occur beyond North America, whereas Barbclabornia is endemic to North America because of a more restricted habitat, similar to O. platypternus (Johnson 1999: 253). 
Occurrences of Barbclabornia in tetrapod-bearing facies, which are dominantly freshwater, suggest it was a freshwater shark.

\section{Dentition and diet of Barbclabornia}

The morphologic differences in Barbclabornia and Orthacanthus teeth suggest they utilized different food sources. Because Barbclabornia had a functionally homodont dentition, its diet must have been different from that of Orthacanthus (Johnson 1999: 252-253). Barbclabornia probably could only bite down on its prey, with the cristae providing additional surface area on the cusps to improve its grasp. Without the presence of slicing teeth, they probably attacked prey they could swallow whole. The presence or absence of an intermediate cusp further suggests a subtle dietary difference between Barbclabornia and Triodus (X.) moorei (Johnson, 1980) and Bransonella (X.?) nebraskensis (Johnson, 1984). There is no consistent pattern of wear facets in the teeth of these species to suggest any influence of the intermediate cusp on occlusion or any functional differences (Johnson 1979: 234-236). Because intermediate cusps would aid in withstanding lateral forces of captured active prey, such as large fish and amphibians, perhaps Barbclabornia sought less active prey, such as arthropods, smaller fish, and small amphibians. The more massive, cristated intermediate cusp in $B .(X$. ?) nebraskensis would increase its grasping ability, allowing it to take larger prey than could $T$. $(X$.) moorei, assuming they were of similar size.

Williams (2001) contrasts the shark dentitions of "graspers and swallowers" (cladodonts and Barbclabornia) with "cutters and gougers" (most modern sharks, but would also include Orthacanthus). He notes that the living sand tiger shark, a grasper and swallower, feeds primarily on bony fishes and sometimes on arthropods and squid. Graspers and swallowers have cylindrical rather than compressed cusps, but the sand tiger and cladodonts have a central, usually cristated, principal cusp with smaller lateral cusps, quite unlike Barbclabornia. Based upon Williams' (2001: table 1) generalities, Barbclabornia may have had gaps between the tooth files with several functional teeth in each file. However, all xenacanths have a labiolingually expanded tooth base, not just the graspers and swallowers.

Small teeth, large shark: Species of Orthacanthus probably possess the largest teeth of any xenacanth shark (see Johnson 1999, for example); palatoquadrates of the species illustrated by Heidtke $(1998,1999)$ do not appear to exceed $30 \mathrm{~cm}$ in length. [Heidtke's (1999) $O$. senckenbergianus is a species of Lebachacanthus (Soler-Gijón 1997, 2000, Hampe 1999).] In contrast, the Oklahoma palatoquadrate of Barbclabornia mentioned above may have had a total length of $45 \mathrm{~cm}$, which translates into a total body length of more than four meters (J. Zidek, pers. comm.). Because tooth size is not related to body length, then speculation about the length of $B$. cf. luedersensis is probably not warranted.

\section{Conclusions}

Barbclabornia luedersensis (Berman, 1970) possessed a functionally homodont dentition. The increase in size of the teeth through time ultimately results in a persistent quadrangular shape of the tooth base in $B$. cf. luedersensis.

Barbclabornia was endemic to North America during its Early Permian existence, and was probably most closely related to Triodus. It probably inhabited a coastal plain freshwater environment.

This study, combined with others in North America and Europe cited above, and potentially with others being conducted in Brazil (M. Richter, pers. comm.), will eventually help to determine the effect of biodiversity patterns (Erwin 1998) on the evolution of the xenacanths.

\section{Acknowledgements}

Those mentioned in Johnson (1999) were also instrumental in supporting and helping with this study. Special recognition goes to Bryce Bell for curatorial assistance in the Johnson (1979) study, and the field and laboratory help from Ronald Ritchie. Also, this study would not have been possible without the permission to conduct field work on the Waggoner Ranch: the hospitality and cooperation provided by Gene Willingham and the late Glen Collier are appreciated. Jiri Zidek graciously provided information on the Lake Frederick palatoquadrate; likewise, Robert Hook provided detailed stratigraphic information regarding the East Coffee Creek 47 local fauna in the Clear Fork Group. Evaldo Wehmuth Ragogna (formerly Ragonha) gratefully provided unpublished photographs of Triodus (X.) moorei(?) teeth from Brazil. Martha Richter permitted me to examine other xenacanth teeth from the Upper Permian Teresina Formation, Paraná Basin; I thank her for her excellent hospitality. The illustrations in Figs 4-11 were drawn by Pat Gasser; those in Fig. 14A-E were drawn by April Gawboy. Preparation of the manuscript was assisted by Jan Strom and especially by Colleen Odenbrett. Support was provided by the National Science Foundation (EAR-8216472, with Phillip A. Murry) and the University of South Dakota College of Arts and Sciences and Office of Research. Loans of specimens and/or 
permission and assistance to study specimens were provided by Mary Dawson and David Berman, Carnegie Museum of Natural History; Carolyn Good, Vertebrate Paleontology Laboratory, University of Texas at Austin; and Dale Winkler, Shuler Museum of Paleontology. Southern Methodist University. Oliver Hampe, Rodrigo Soler-Gijón, Robert Hook, and Martha Richter provided useful comments on the initial manuscript submitted to the editor. Their efforts afforded much improvement. Finally, this study and all associated endeavors would not have been possible without the patience and assistance of the late Professor Bob H. Slaughter.

\section{References}

Applegate, S. P. 1965. Tooth terminology and variation in sharks with special reference to the sand shark, Carcharias taurus Rafinesque. - Los Angeles County Museum Contributions in Science 87: 3-18

Baars, D. L. 1990. Permian chronostratigraphy in Kansas. Geology 18: 687-690.

Berg, L. S. 1940. Classification of fishes, both recent and fossil.- Trudy Zoologischeskogo Instituta Akademii Nauk (Travaux de l'Institut Zoologique de l'Académie des Sciences de l'URSS) 5: 85-517. [also published in 1947 by J. W. Edwards, Ann Arbor.]

Berman, D. S. 1970. Vertebrate fossils from the Lueders Formation, Lower Permian of north-central Texas. - University of California, Publications in Geological Sciences 86: $1-61$.

Bonaparte, C. L. 1838. Synopsis vertebratorum systematis.Nuovi Annali Delle Scienze Naturali II: 105-133.

Erwin, D. H. 1998. After the end: Recovery from extinction. - Science 279: 1324-1325.

Fritsch, A. 1889. Fauna der Gaskohle und der Kalksteine der Permformation Böhmens, v. 2.114 pp. +42 pls., F. Řivnáč, Praha.

Hampe, O. 1988. Über die Bezahnung des Xenacanthus (Chondrichthyes: Xenacanthida; Unterperm, SW-Deutschland). - Neues Jahrbuch für Geologie und Paläontologie, Monatshefte, 1988: 743-756.

- 1989. Revision der Triodus-Arten (Chondrichthyes: Xenacanthida) aus dem saarpfälzischen Rotliegenden (Oberkarbon-Perm, SW-Deutschland) aufgrund ihrer Bezahnung. - Paläontologische Zeitschrift 63: 79-101.

- 1991. Histologische Untersuchungen an fossilen Zähnen der Haifisch-Ordaung Xenacanthida (Chondrichthyes: Elasmobranchii) mit Hilfe der Fluoreszenzmikroskopie. Leica, Mitteilungen für Wissenschaft und Technik 10: $17-27$.

- 1993. Variation of xenacanthid teeth in the Permo-Carboniferous deposits of the Saar-Nahe Basin (SW-Germany). In Heidtke, U. (compiler). New Research on Permo-Carboniferous Faunas. - Pollichia-Buch 29: 37-51.

- 1994. Neue Erkenntnisse zur permokarbonischen Xenacanthiden-Fauna (Chondrichthyes: Elasmobranchii) und deren Verbreitung im südwestdeutschen Saar-NaheBecken. - Neues Jahrbuch für Geologie und Paläontologie, Abhandlungen 192: 53-87.

- 1997. Dental growth anomalies and morphological changes in teeth of the Xenacanthida (Lower Permian; Saar-Nahe Basin, SW-Germany). - Modern Geology 21: $121-135$.

- 1999. Revision of the Xenacanthida (Chondrichthyes: Elasmobranchii) from the Carboniferous of the British Isles: final results. In Luksevics, E., Stinkulis, G. \& Wilson, M. V. H. (eds). Lower-Middle Palaeozoic events across the Circum-Arctic. - Ichthyolith Issues, Special Publication 5: 20-21 (abstract).

Hampe, O. \& Heidtke, U. H. J. 1997. Hagenoselache sippeli n. gen. n. sp. ein früher xenacanthider Elasmobranchier aus dem Oberkarbon (Namurium B) von Hagen-Vorhalle
(NW-Sauerland/Deutschland). - Geologie und Paläontologie in Westfalen 47: 5-42.

Hampe, O. \& Long, J. A. 1999. The histology of Middle Devonian chondrichthyan teeth from southern Victoria Land, Antarctica. In Baynes, A. \& Long, J. A. (eds). Papers in Vertebrate Paleontology. - Records of the Western Australian Museum 57: 23-36.

Hansen, M. C. 1996. Phylum Chordata - vertebrate fossils. In Feldmann, R. M. \& Hackathorn, M. (eds). Fossils of Ohio. - Ohio Division of Geological Survey, Bulletin 70: 288-369.

Heidtke, U. H. J. 1998. Revision der gattung Orthacanthus Agassiz 1843 (Chondrichthyes: Xenacanthida). - Paläontologische Zeitschrift 72: 135-147.

- 1999. Orthacanthus (Lebachacanthus) senckenbergianus Fritsch 1889 (Xenacanthida: Chondrichthyes): revision, organisation und phylogenie. - Freiberger Forschungsheft (C) 481: 63-106.

Hentz, T. F. 1988. Lithostratigraphy and paleoenvironments of upper Paleozoic continental red beds, North-Central Texas: Bowie (new) and Wichita (revised) Groups. - The University of Texas at Austin, Bureau of Economic Geology Report of Investigations 170: 1-55.

Hentz, T. F. \& Brown, Jr., L. F. 1987. Wichita Falls-Lawton sheet. In Barnes, V. E. (project director). Geologic Atlas of Texas. The University of Texas at Austin, Bureau of Economic Geology, scale $1: 250,000$.

Hotton, N. 1952. Jaws and teeth of American xenacanth sharks. - Journal of Paleontology 26: 489-500.

Huxley, T. H. 1880. On the application of the laws of evolution to the arrangement of the Vertebrata and more particularly of the Mammalia. - Proceedings of the Scientific Meetings of the Zoological Society of London 1880: 649-662. [also In Foster, M. \& Lankester, E. R. (eds). The Scientific Memoirs of Thomas Henry Huxley, Vol IV, 1902: 457-472, Macmillan and Co., London.]

Johnson, G. D. 1979. Early Permian vertebrates from Texas: Actinopterygii (Schaefferichthys), Chondrichthyes (including North American Pennsylvanian and Triassic Xenacanthodii), and Acanthodii. 653 pp., Unpublished Ph.D. dissertation, Southern Methodist University, Dallas. [available from University Microfilms International, Ann Arbor and London (listed as 1980)]

- 1980. Xenacanthodii (Chondrichthyes) from the Tecovas Formation (Late Triassic) of West Texas. - Journal of Paleontology 54: 923-932.

- 1981a. Hybodontoidei (Chondrichthyes) from the Wichita-Albany Group (Early Permian) of Texas. - Journal of Vertebrate Paleontology 1: $1-41$.

- 1981b. A Permian-?Pennsylvanian chondrichthyan microfauna from lowermost Wichita-Albany Group in NorthCentral Texas. - Bulletin, American Association of Petroleum Geologists 85: 941-942 (abstract).

- 1984. A new species of Xenacanthodii (Chondrichthyes, Elasmobrachii) from the Late Pennsylvanian of Nebraska. In Mengel, R. M. (ed.). Papers in Vertebrate Paleontology Honoring Robert Warren Wilson. - Special Publication of Carnegie Museum of Natural History 9 : $178-186$.

- 1987. Deformed xenacanthodiid shark teeth from the Permian of Texas. In Martin, J. E. \& Ostrander, G. E. (eds). Papers in Vertebrate Paleontology Honoring Morton Green. - Dakoterra 3: 22-27.

- 1992a. Chondrichthyan biostratigraphy of the North American Permian System. In Nairn, A. E. M. \& Koroteev, V. (eds). Contributions to Eurasian Geology. Papers Presented at the International Congress on the Permian System of the World, Perm, Russia, 1991-Part 1. - Occasional Publications ESRI, New Series 8B: 41-50.

- 1992b. Early Permian vertebrate microfossils from Archer City Bonebed 3, Archer County, Texas. - Journal of Vertebrate Paleontology 12 (Supplement to No. 3, Abstracts): $35 \mathrm{~A}-36 \mathrm{~A}$. 
- 1996. Vertebrate microfossils from the Lueders Formation. Albany Group, and the faunal transition from the Wichita Group into the Clear Fork Group, Lower Permian of Texas. - Modern Geology 20: 371-382.

- 1999. Dentitions of Late Palaeozoic Orthacanthus species and new species of ?Xenacanthus (Chondrichthyes: Xenacanthiformes) from North America. - Acta Geologica Polonica 49: 215-266.

- 2000. Upper Paleozoic endemic genera of Xenacanthiformes (Chondrichthyes, Elasmobranchii): a global perspective. $31^{\text {st }}$ International Geological Congress Abstracts Volume: CD-ROM (n. pag.), Versāo Brasileria, Rio de Janeiro.

Johnson, G. D. \& Zidek, J. 1981. Late Paleozoic phyllodont tooth plates. - Journal of Paleontology 55: 524-536.

Laurin. M. \& Soler-Gijón. R. 2001. The oldest stegocephalian from the Iberian Peninsula: evidence that temnospondyls were euryhaline. - Comptes Rendus de l'Académie des Sciences, Paris, Sciences de la vie/Life Sciences 324: 495-501.

Lund, R. 1970. Fishes from the Duquesne Limestone (Conemaugh, Pennsylvanian), Part I: fossil fishes from southwestern Pennsylvania. - Annals of Carnegie Museum 41: $231-261$.

- 1976. General geology and vertebrate biostratigraphy of the Dunkard Basin. In Falke. H. (ed.). The Continental Permian in Central. West, and South Europe: 225-239. D. Reidel Co., Dordrecht.

Murry, P. A. \& Johnson, G. D. 1987. Clear Fork vertebrates and environments from the Lower Permian of NorthCentral Texas. - Texas Journal of Science 39: 253-266.

Nelson, W. J., Hook. R. W. \& Tabor. N. 2001. Clear Fork Group (Leonardian. Lower Permian) of North-Central Texas. In Johnson. K. S. (ed.). Pennsylvanian and Permian geology and petroleum in the southern Midcontinent. 1998 symposium: 167-169, Oklahoma Geological Survey Circular 104.

Olson, E. C. 1967. Early Permian vertebrates of Oklahoma. - Oklahoma Geological Survey Circular 74: 1-111.

- 1971. Vertebrate Paleozoology. 839 pp., Wiley-Interscience, New York.

- 1989. The Arroyo Formation (Leonardian: Lower Permian) and its vertebrate fossils. - Texas Memorial Museum Bulletin 35: 1-25.

Ørvig. T. 1967. Phylogeny of tooth tissues: Evolution of some calcified tissues in early vertebrates. In Miles. A. E. W. (ed.). Structural and Chemical Organization of Teeth: 45-110, Academic Press, Inc., New York.

Ossian, C. R, 1974. Paleontology, paleobotany, and facies characteristics of a Pennsylvanian delta in southeastern Nebraska. 393 pp., Unpublished Ph.D. dissertation. University of Texas, Austin.

Parrish, W. C. 1978. Paleoenvironmental analysis of a Lower Permian bonebed and adjacent sediments, Wichita County, Texas. - Palaeogeography, Palaeoclimatology, Palaeoecology 24: 209-237.

Peyer, B. 1968. Comparative Odontology (trans. and ed. by R. Zangerl). 347 pp., University of Chicago Press. Chicago.

Poole. D. F. G. 1967. Phylogeny of tooth tissues: Enameloid and enamel in Recent vertebrates, with a note on the history of cementum. In Miles. A. E. W. (ed.). Structural and Chemical Evolution of Teeth: 111-149. Academic Press, Inc., New York.

Reif. W.-E. 1977. Tooth enameloid as a taxonomic criterion: 1. A new euselachian shark from the Rhaetic-Liassic boundary.- Neues Jahrbuch für Geologie und Paläontologie, Monatshefte 9: 565-576.

Rieppel, O. 1981. The hybodontiform sharks from the Middle Triassic of Mte. San Giorgio, Switzerland. - Neues Jahrbuch für Geologie und Paläontologie, Abhandlungen 161: 324-353.

Sander, P. M. 1989. Early Permian depositional environments and pond bonebeds in central Archer County, Texas. Palaeogeography, Palaeoclimatology, Palaeoecology 69: $1-21$.

- 2000. Prismless enamel in amniotes: terminology, function, and evolution. In Teaford, M. F., Smith, M. M. \& Ferguson, M. W. J. (eds). Development, Function and Evolution of Teeth: 92-106, Cambridge University Press, Cambridge.

Schneider, J. W. \& Zajíc, J. 1994. Xenacanthiden (Pisces, Chondrichthyes) des mitteleuropäischen Oberkarbon und Perm - Revision der Originale zu Goldfuss 1847, Beyrich 1848, Kner 1867 und Fritsch 1879-1890. - Freiberger Forschungshefte (C) 452: 101-151.

Schultze, H.-P. 1985. Marine to onshore vertebrates in the Lower Permian of Kansas and their paleoenvironmental implications. - University of Kansas Paleontological Contributions, Paper 113: 1-18.

Sequeira, S. E. K. 1998. The cranial morphology and taxonomy of the saurerpetontid Isodectes obtusus comb. nov. (Amphibia: Temnospondyli) from the Lower Permian of Texas. - Zoological Journal of the Linnean Society 122: 237-259.

Simpson, G. G., Roe, A. \& Lewontin, R. C. 1960. Quantitative Zoology, rev. ed. 440 pp., Harcourt Brace and Co., New York.

Simpson, L. C. 1979. Upper Gearyan and Lower Leonardian terrestrial vertebrate faunas of Oklahoma. - Oklahoma Geology Notes 39: 3-21.

Smith. M. M. \& Sansom, I. J. 2000. Evolutionary origins of dentine in the fossil record of early vertebrates: diversity, development and function. In Teaford, M. F., Smith, M. M. \& Ferguson, M. W. J. (eds). Development, Function and Evolution of Teeth: 65-81. Cambridge University Press, Cambridge.

Soler-Gijón, R. 1997. New discoveries of xenacanth sharks from the Late Carboniferous of Spain (Puertollano Basin) and Early Permian of Germany (Saar-Nahe Basin): Implications for the phylogeny of xenacanthiform and anacanthous sharks. - Neues Jahrbuch für Geologie und Paläontologie, Abhandlungen 205: 1-31.

- 2000. Phylogenetic relationships of Lebachacanthidae Soler-Gijón 1997 (Xenacanthiformes; Elasmobranchii). Paläontologische Zeitschrift 74: 363-377.

Stritzke, R. 1986. Xenacanthid shark teeth in Middle Devonian limestones of the Rhenish Schiefergebirge, West Germany. - Journal of Paleontology 60: 1134-1135.

Williams. M. E. 2001. Tooth retention in cladodont sharks: with a comparison between primitive grasping and swallowing, and modern cutting and gouging feeding mechanisms. - Journal of Vertebrate Paleontology 21: 214-226. 